\title{
HDLs inhibit endoplasmic reticulum stress and autophagic response induced by oxidized LDLs
}

\author{
C Muller ${ }^{1,2}$, R Salvayre ${ }^{1,2}$, A Nègre-Salvayre ${ }^{1}$ and C Vindis ${ }^{\star, 1}$
}

The apoptotic effect of oxidized LDLs (oxLDLs) is mediated through a complex sequence of signaling events involving a deregulation of the cytosolic $\mathrm{Ca}^{2+}$ homeostasis. OxLDLs also trigger ER stress that may lead to cellular dysfunction and apoptosis, through the activation of the IRE1 a/c-Jun N-terminal kinase pathway. Moreover, ER stress and oxidized lipids have been shown to trigger autophagy. The antiatherogenic high-density lipoproteins (HDLs) display protective effects against oxLDLs toxicity. To more deeply investigate the mechanisms mediating the protective effects of HDLs, we examined whether ER stress and autophagy were implicated in oxLDLs-induced apoptosis and whether HDLs prevented these stress processes. We report that, in human endothelial cells, HDLs prevent the oxLDL-induced activation of the ER stress sensors IRE $1 \alpha$, elF $2 \alpha$ and ATF6 and subsequent activation of the proapoptotic mediators JNK and CHOP. OxLDLs also trigger the activation of autophagy, as assessed by LC3 processing and Beclin-1 expression. The autophagic process is independent of the proapoptotic arms of ER stress, but Beclin-1 contributes to PS exposure and subsequent phagocytosis of oxLDLs exposed cells. Induction of autophagy and PS exposure by oxLDLs is prevented by HDLs. Finally, the cytosolic $\mathrm{Ca}^{2+}$ deregulation triggered by oxLDLs is a common signaling pathway that mediates ER stress-induced cell death and autophagy, all these events being blocked by HDLs.

Cell Death and Differentiation (2011) 18, 817-828; doi:10.1038/cdd.2010.149; published online 26 November 2010

An initiating event in atherogenesis is the accumulation of lowdensity lipoproteins (LDLs) in the subendothelial space where they may undergo oxidative modifications. ${ }^{1}$ Oxidized LDLs (oxLDLs) exhibit a variety of atherogenic properties including foam cell formation, inflammatory response, cell proliferation at low concentration and apoptosis at higher concentration ${ }^{1,2}$ OxLDLs may alter the fragile balance between survival and death of vascular cells, thereby, leading to plaque instability and finally to atherothrombotic events. ${ }^{3,4}$ The proapoptotic effects of oxLDLs are mediated through a complex sequence of signaling events that lead to the activation of several caspase-dependent or caspase-independent apoptotic pathways $^{2,5,6}$ Previously, we reported that treatment of human vascular endothelial and smooth muscle cells with oxLDLs or 7-ketocholesterol (a major oxysterol in oxLDLs) causes an increase in cytosolic $\mathrm{Ca}^{2+}$ through TRPC1 channels that triggers a proteolytic cascade involving $\mathrm{Ca}^{2+}$-dependent calpains, Bid cleavage and cytochrome $c$ release, leading finally to caspase-3 activation and apoptosis. ${ }^{7-9}$

Recently, we have reported that oxLDLs induced the unfolded protein response (UPR) and triggered endoplasmic reticulum (ER) stress. ${ }^{9} \mathrm{ER}$ is a sensor for cellular stress, as it rapidly detects changes in cell homeostasis, and responds by triggering UPR via the activation of ER transmembrane sensors, PERK and IRE $1 \alpha$ (two serine/threonine kinases), and ATF6 which acts as a transcription factor. The UPR results in a temporary downregulation of protein translation, an upregulation of ER chaperones and folding machinery, and the expression and activation of ER-associated degradation (ERAD). Prolonged ER stress switches toward apoptotic cell death via the activation of downstream signals like CHOP, JNK and members of the Bcl-2 family. ${ }^{10,11}$ ER stress markers (phosphorylation of IRE1 $\alpha$ and expression of KDEL motifbearing proteins) in human advanced atherosclerotic lesions, ${ }^{9}$ raising the question of the possible role of ER stress in the stability/unstability of atherosclerotic plaques, as this new adaptative response may determine the fate of cells to survive or die. ${ }^{11}$ Autophagy is involved in the turnover of cellular macromolecules, ${ }^{12}$ which could mediate, in part, the removal of ER-accumulated protein, via the ER-associated chaperone GRP78/Bip, ${ }^{13}$ and the release of $\mathrm{Ca}^{2+}$ from the ER into the cytosol. ${ }^{14}$ Striking observations link ER stress with autophagy, which is rather considered as an antiatherogenic mechanism, as it could selectively induce macrophage cell death, which is thought to limit inflammation and has a protective role in vulnerable plaque stabilization. ${ }^{15}$ Although

\footnotetext{
${ }^{1}$ INSERM U-858, Department of Vascular Biology, IFR-150, CHU Rangueil, Toulouse, France and ${ }^{2}$ Faculty of Medicine, University Paul Sabatier, Toulouse, France ${ }^{*}$ Corresponding author: C Vindis, INSERM U858/I2MR Department of Vascular Biology, IFR150, Hopital Rangueil 1, avenue Jean Poulhès, BP 84225,31432 Toulouse cedex 4, France. Tel: + 3356132 2705; Fax: + 3356132 2953; E-mail: cecile.vindis @ inserm.fr

Keywords: oxidized LDLs; HDLs; ER stress; calcium; autophagy; apoptosis

Abbreviations: Apo, apolipoprotein; ATF, activating transcription factor; Bcl-2, B-cell lymphoma 2; BiP, binding immunoglobulin protein; $\mathrm{CHOP}, \mathrm{C} / \mathrm{EBP}$ homologous protein; EGTA, ethylene glycol-bis ( $\beta$ amino-ethylether)-N,N,N',N', -tetraacetic acid; elF2 $\alpha$, eucaryotic translation initiation factor -2, $\alpha$ subunit; ER, endoplasmic reticulum; ERAD, endoplasmic reticulum associated degradation; GRP78, 78-kDa glucose-regulated protein; HDL, high-density lipoprotein; HMEC-1, human microvascular endothelial cell-1; IRE1 $\alpha$, Inositol-requiring kinase $1 \alpha$; JNK, c-Jun N-terminal kinase; KDEL, ER retention peptide KDEL (i. e.,, Lys Asp Glu Leu); LC3, microtubuleassociated protein-1 light-chain 3; 3-MA, 3-methyladenine; MEF, mouse embryonic fibroblasts; mTOR, mammalian target of rapamycin; MTT, 3-(4,5-dimethylthiazol-2yl)-2, 5-diphenyltetrazolium bromide; NF-KB, nuclear factor- $\kappa$ B; oxLDLs, oxidized Low-density lipoproteins; PERK, PKR (protein kinase regulated by RNA) like endoplasmic reticulum Kinase; PI, propidium iodide; PS, phosphatidylserine; siRNA, small interfering RNA; TRAF2, TNF receptor-associated factor 2; TRPC1, transient receptor potential canonical channel 1; UPR, unfolded protein response; XBP1s, X-box-binding protein 1 spliced form

Received 12.2.10; revised 23.9.10; accepted 14.10.10; Edited by H-U Simon; published online 26.11.10
} 
considered as a survival mechanism, autophagy may also mediate a non-apoptotic cell death in case of prolonged ER stress, or when apoptotic pathways are blocked. ${ }^{16}$

Contrary to LDLs, high-density lipoproteins (HDLs) exhibit antiatherogenic and cardioprotective properties. ${ }^{17}$ Besides their classical function in the reverse cholesterol transport, HDLs possess anti-inflammatory and antioxidant properties. ${ }^{18}$ HDLs inhibit LDLs oxidation, and counteract several adverse biological effects, such as cytotoxicity and inflammatory response triggered by cytokines, oxLDLs or oxidants. ${ }^{18,19}$ HDLs counterbalance the proinflammatory effect of oxLDLs by inhibiting intracellular reactive oxygen species rise and subsequent NF- $\kappa \mathrm{B}$ activation in vascular cells, ${ }^{20}$ and by preventing the formation of oxLDLs-induced carbonyl-protein adducts. ${ }^{8}$ Recently, the anti-inflammatory role of HDLs has been linked to a reduced induction of ER stress elicited by oxidized phospholipids, including the expression of ATF-3, ATF-4 and spliced XBP1 genes. ${ }^{21}$ In view of the literature, the multiple molecular mechanisms implicated in the antiatherogenic effect of HDLs are only partly understood.

In the current study, we report that HDLs are able to prevent both ER stress/UPR induction and autophagic response triggered by oxLDLs. This protective effect of HDLs is mediated, by their ability to prevent the cytosolic $\mathrm{Ca}^{2+}$ deregulation evoked by oxLDLs, behind the activation of ER stress and autophagy.

\section{Results}

ER stress induced by oxLDLs is prevented by HDLs in endothelial cells. We recently reported that oxLDLs induce the activation of the three ER stress sensors as assessed by the phosphorylation of IRE $1 \alpha$, PERK and of the PERK substrate elF $2 \alpha$ and by the nuclear translocation of ATF $6 .{ }^{9}$ In the present study, we investigated the effect of HDLs on the activation of these ER stress sensors elicited by oxLDLs stimulation. Our data show that pre-treatment of HMEC-1 cells with HDLs, followed by coincubation with oxLDLs significantly reduced the time-dependent phosphorylation of IRE $1 \alpha$ and elF2 $\alpha$ (Figure $1 a$ and $b$ ). Likewise, the detection of the transcription factor ATF6 in cells treated with oxLDLs, indicative of the release of its cytosolic domain was prevented by HDLs (Figure 1c). Activation of IRE $1 \alpha$ and ATF6 promotes the transcription of UPR target genes such as spliced XBP1 mRNA. Consistent with the inhibitory effect observed on IRE $1 \alpha$ and ATF6, the induction of spliced XBP1 mRNA by oxLDLs was reduced by HDLs to $40 \%$ compared with oxLDLs-treated cells (Figure 1d). We also investigated the activation of the caspase-12, which is located at the ER and activated by excess ER stress through IRE $1 \alpha^{25}$ In mouse endothelial cells, oxLDLs treatment leads to the processing of caspase-12, which is partly prevented by HDLs (Figure 1e).

Collectively, these data indicate that HDLs inhibit the activation of ER stress sensors induced by oxLDLs. As oxLDLs trigger a prolonged ER stress activation, which may have a role in apoptotic cell death through the IRE1-TRAF2-JNK pathway and CHOP expression, ${ }^{9}$ we then checked the effect of HDLs on the ER stress-dependent apoptotic signaling.

JNK activation and CHOP expression, two ER stress proapoptotic mediators activated by oxLDLs, are inhibited by HDLs. Toxic concentrations of oxLDLs trigger a time-dependent activation of the JNK pathway and expression of CHOP mRNA and protein (Figure $2 a$ and $b$ ). The same conditions elicit apoptosis as evaluated by cell viability and morphological analysis of cells stained by SYTO-13/PI and May-Grünwald-Giemsa (Figure 2c and e). JNK and CHOP are implicated in oxLDLs-induced apoptosis, as suggested by the protective effect of the JNK inhibitor SP600125, CHOP-specific siRNA and the use of mouse embryonic fibroblasts $\mathrm{CHOP}^{-1-}\left(\mathrm{MEFs} \mathrm{CHOP}^{-1-}\right.$ ) (Figure 2c and d).

Interestingly, the protective role of HDLs against the apoptotic effect of oxLDLs, was correlated with the potent inhibitory effect of HDLs against JNK activation and CHOP expression triggered by oxLDLs (Figure $2 \mathrm{a}-\mathrm{c}$ and $\mathrm{e}$ ).

Taken together, these results suggest that the protective effect of HDLs may result, in part, from their ability to inhibit the oxLDLs-induced ER stress and subsequent ER stressdependent activation of JNK and CHOP expression.

Autophagic markers expression induced by oxLDLs is prevented by HDLs. As oxidized lipids and oxidative stress may trigger autophagy in vascular cells ${ }^{26,27}$ as well as ER stress, ${ }^{9}$ and as autophagy may act as a protective mechanism or a death process, we investigated whether, autophagy was activated by oxLDLs and whether HDLs interfere with autophagic process.

During autophagosome formation, the unconjugated soluble form LC3-I is processed and converted to the phosphatidylethanolamine (PE)-conjugated form (LC3-II), which is then incorporated into autophagosomal membrane. ${ }^{28}$ Our results show that oxLDLs trigger a time-dependent increase in LC3-II and the occurrence of LC3-positive dots as a sign of autophagy in HMEC-1 (Figure $3 a$ and b). In contrast, pretreatment of cells with HDLs, inhibited the rise of LC3-II, and the formation of LC3-positive dots in cells treated by oxLDLs (Figure $3 a$ and $b$ ). To confirm the activation of autophagy by oxLDLs, we examined the expression status of Beclin-1, a protein which participates in a complex essential for autophagy and whose expression is increased during autophagy. ${ }^{29}$ Time course experiments showed an increased expression of Beclin-1, (Figure 3c and d), thus, supporting the hypothesis that oxLDLs trigger the expression of autophagic markers. Similar to the inhibition of LC3 processing by HDLs, Beclin-1 expression was downregulated by HDLs pre-treatment.

In order to examine whether autophagy process induced by oxLDLs is relevant to atherogenesis, we investigated whether oxLDLs induced autophagic markers in human macrophages. OxLDLs triggered a time-dependent increase in LC3-II in $\mathrm{U}-937$ cells (Figure 4a). This is in agreement with previous studies showing the stimulation of autophagy by oxidized lipids in plaque cells. ${ }^{15}$ Interestingly, our results show for the first time in macrophages that the oxLDL-induced autophagic 


\section{a}
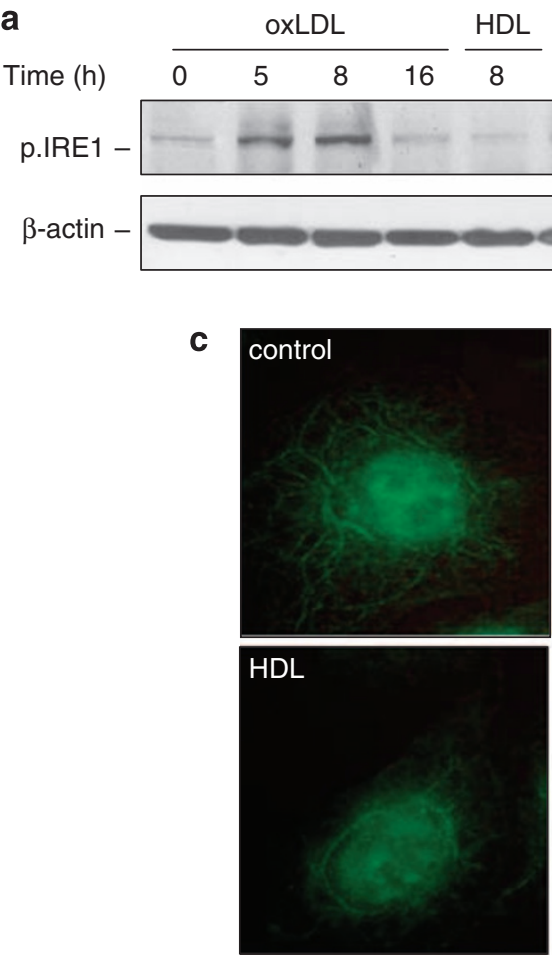

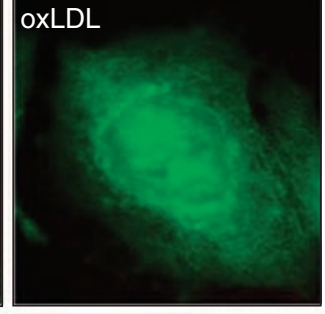

oxLDL+ HDL

b

\begin{tabular}{|c|c|c|c|c|c|}
\hline b & & oxLDL & & HDL & oxLDL + HDL \\
\hline Time (h) & 0 & 5 & 16 & 8 & 16 \\
\hline
\end{tabular}

p.elF2 $\alpha$

$\beta$-actin -
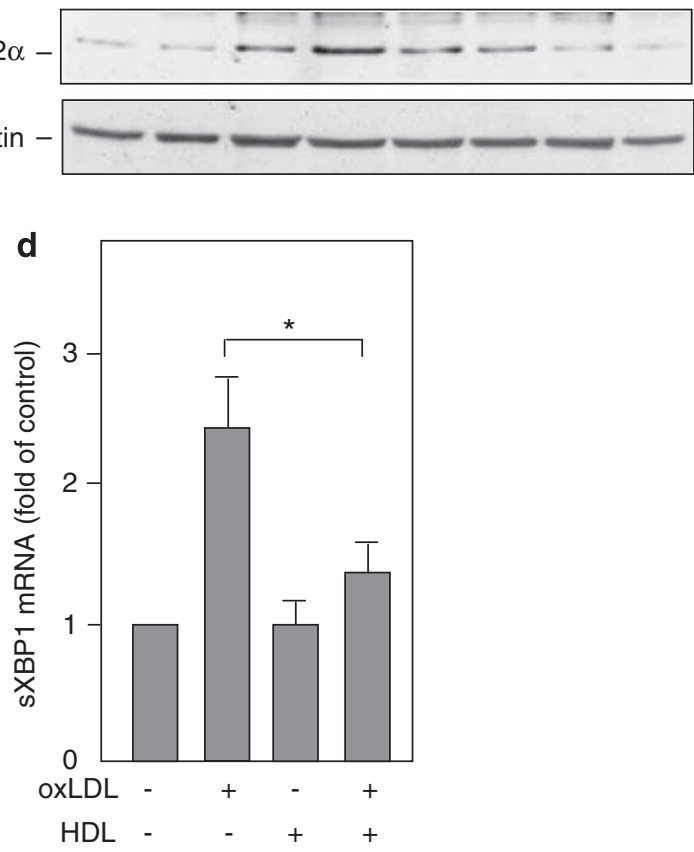

e

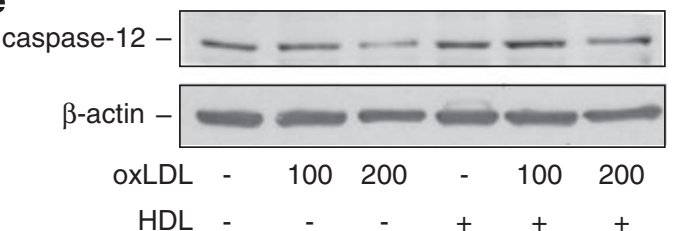

Figure 1 HDLs prevent oxLDLs-triggered UPR/ER stress activation in HMEC-1 cells and caspase-12 processing in mouse endothelial cells. Time course of phosphorylation of IRE $1 \alpha$ and elF2 $\alpha$ in HMEC-1 cells treated with oxLDLs $(200 \mu \mathrm{g} \mathrm{ApoB} / \mathrm{ml})$ or pre-incubated with HDLs $(200 \mu \mathrm{g} \mathrm{ApoA} / \mathrm{ml})$ for $1 \mathrm{~h}$. Cell lysates were assessed for phospho-IRE1 $\alpha$ (a) and phospho-elF2 $\alpha$ (b) protein expression by western blot analysis, $\beta$-actin expression was used as protein loading control. (c) Immunocytochemistry experiments show the cytoplasmic and nuclear translocation of ATF6 in HMEC-1 cells treated with oxLDLs $(200 \mu \mathrm{g} \mathrm{ApoB} / \mathrm{ml})$ for $16 \mathrm{~h}$ or pre-incubated with HDLs (200 $\mu \mathrm{g}$ $\mathrm{ApoA} / \mathrm{ml}$ ) for $1 \mathrm{~h}$. These data are representative of three separate experiments. (d) Real-time PCR experiments showing mRNA expression of human spliced form XBP1 (sXBP1) in HMEC-1 cells treated with oxLDLs (200 $\mu \mathrm{g} \mathrm{ApoB} / \mathrm{ml})$ for $16 \mathrm{~h}$ or pre-treated with $\mathrm{HDLs}(200 \mu \mathrm{g} \mathrm{ApoA} / \mathrm{ml})$ for $1 \mathrm{~h}$, relative mRNA levels were normalized to GAPDH mRNA. The data are expressed as mean \pm S.E.M. of four separate experiments, ${ }^{*} P<0.05$ indicates significance (comparison between $0 x L D L$ and $O x L D L+H D L$ groups). (e) Processing of procaspase-12 in mouse endothelial cells treated with oxLDLs (100 or $200 \mu \mathrm{g} \mathrm{ApoB} / \mathrm{ml}$ ) or pre-incubated with HDLs (200 $\mu \mathrm{g} \mathrm{ApoA/ml)} \mathrm{for} 1 \mathrm{~h}$. Cell lysates were assessed for caspase-12 protein expression by western blot analysis, $\beta$-actin expression was used as protein loading control. Blots are representative of three independent experiments

process is downregulated by HDLs (Figure 4a), as well as apoptosis (Figure $4 \mathrm{~b}$ and $\mathrm{c}$ ).

We next investigated whether the autophagic response has a role in oxLDLs-induced cell death. Indeed, excessive or prolonged autophagy may ultimately lead to cell death either in collaboration with apoptosis or as a backup mechanism when the former is defective. ${ }^{16}$ To assess whether autophagy has a role in oxLDLs-induced apoptosis, Beclin-1 was silenced by siRNA treatment. Beclin-1 siRNA were used here because they exhibit no toxic effect per se, whereas the prolonged treatment with the classical autophagic inhibitor 3-methyl-adenine (3-MA) was toxic for the HMEC-1, under the used conditions.

The inhibitory effect of siRNA on Beclin-1 expression became obvious $48 \mathrm{~h}$ after transfection (Figure $5 \mathrm{a}$ ). Beclin-1 silencing did not alter the rate of cell death induced by oxLDLs treatment in HMEC-1, as evaluated by the MTT assay and morphological analysis of cells (Figure $5 \mathrm{~b}$ ). It should be noted that similar results were obtained in macrophages, as inhibition of autophagy by 3-MA (which did not exhibit toxic effect in U-937 cells) did not affect oxLDL-induced cell death (Figure 4c).

To substantiate that autophagy is not involved in oxLDLsinduced apoptosis, but instead could be a stress response concomitant with ER stress, we performed quantitation of annexin $\mathrm{V}$ binding to apoptotic cells. Surprisingly, Beclin-1 silencing by siRNA led to a decreased proportion of annexin V-positive cells, as compared with scramble siRNA (Figure 5c). This discrepancy between annexin V, SYTO-13/ PI labeling and MTT assay may be explained by the fact that oxLDLs-triggered autophagy may be implicated in the phosphatidylserine (PS) exposure process, but has only a 
a

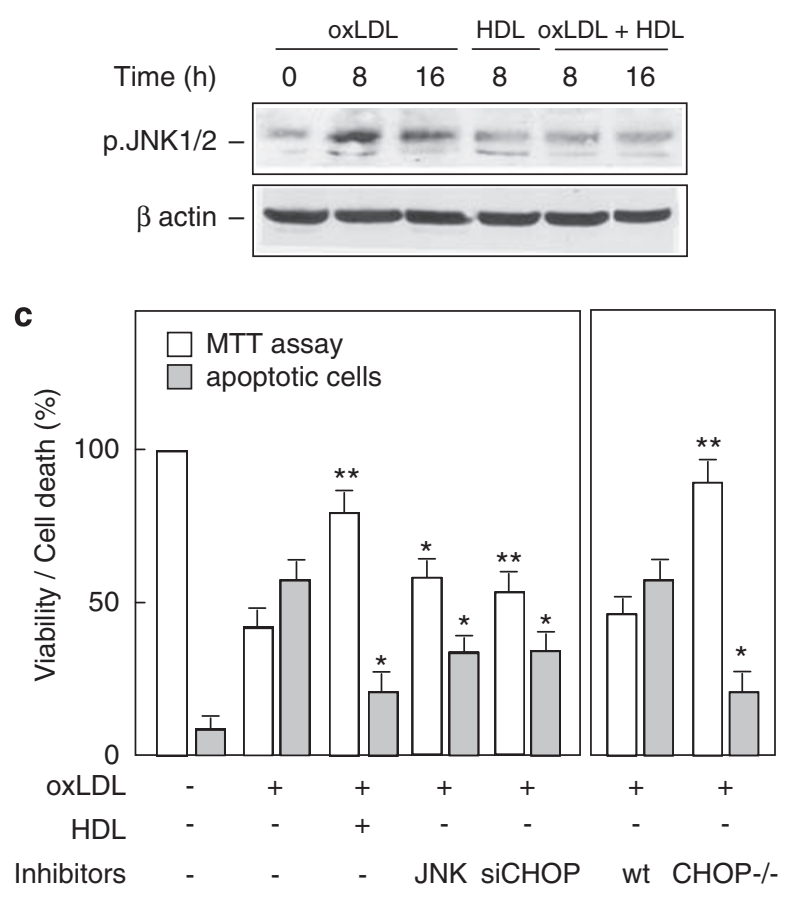

e
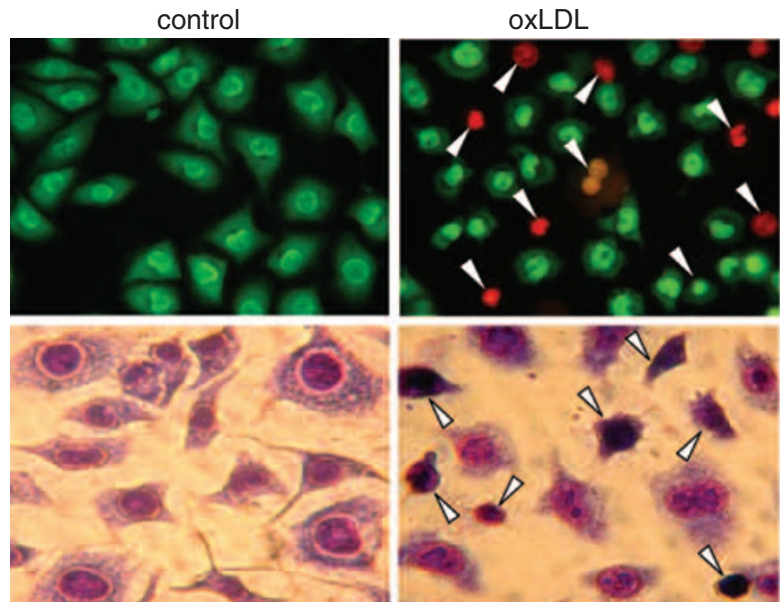

b
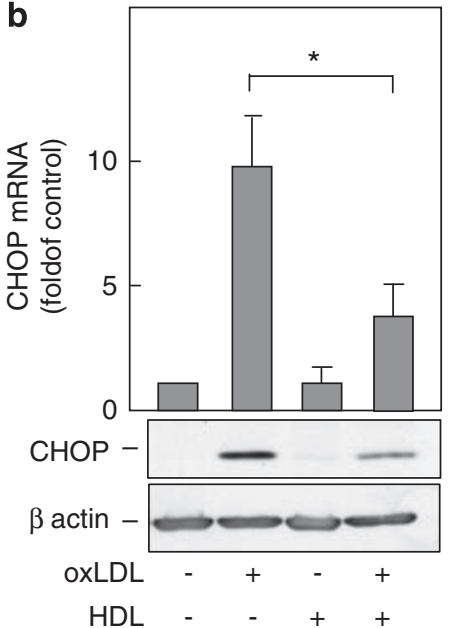

d
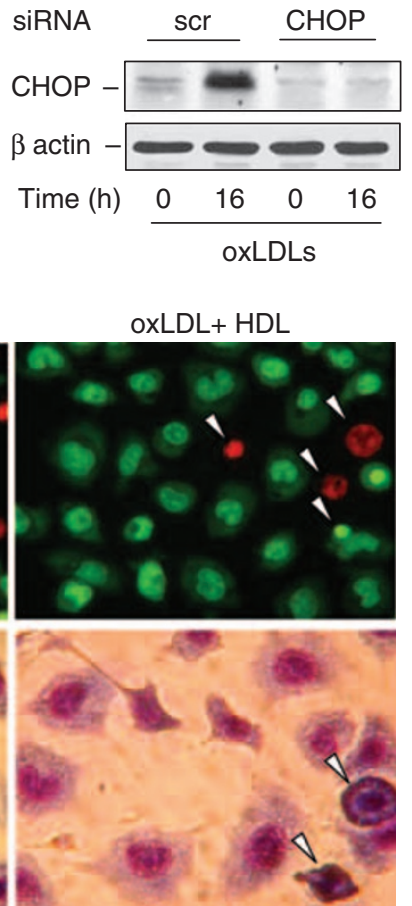

Figure 2 CHOP surexpression, JNK activation and apoptosis induced by oxLDLs are inhibited by HDLs in HMEC-1 cells. (a) Time course of JNK phosphorylation in HMEC-1 cells treated with oxLDLs ( $200 \mu \mathrm{g} \mathrm{ApoB} / \mathrm{ml})$ or pre-treated with $\mathrm{HDLs}(200 \mu \mathrm{g} \mathrm{ApoA} / \mathrm{ml})$ for $1 \mathrm{~h}$. Western blot experiments were performed on total protein extracts using anti-phospho-JNK antibody and $\beta$-actin expression was used as loading control. (b) Real-time PCR (upper panel) and western blot experiments (lower panel) were performed to analyze CHOP mRNA and protein expression levels. HMEC-1 cells were treated with oxLDLs (200 $\mu \mathrm{g} \mathrm{ApoB} / \mathrm{ml})$ for $16 \mathrm{~h}$ or pre-treated with HDLs (200 $\mu \mathrm{g}$ ApoA/ $\mathrm{ml}$ ) for $1 \mathrm{~h}$. Relative mRNA levels were normalized to GAPDH mRNA (upper panel). The data are expressed as mean \pm S.E.M. of four separate experiments, ${ }^{*} P<0.05$ indicates significance (comparison between OxLDL and OxLDL $+\mathrm{HDL}$ groups). Cell lysates were assessed for CHOP protein expression by western blot analysis, $\beta$-actin expression was used as protein loading control. Blots are representative of three independent experiments. (c left panel) Cell toxicity was evaluated by the MTT assay and apoptotic cells were counted after staining with SYTO13/PI. HMEC-1 cells were pre-treated with HDLs (200 $\mu \mathrm{g} \mathrm{ApoA} / \mathrm{ml})$, JNK inhibitor SP600125 (10 $\mu \mathrm{mol} / \mathrm{l})$ or siRNA CHOP (siCHOP) $100 \mathrm{nM}$ then treated with oxLDLs (200 $\mu \mathrm{g} \mathrm{ApoB} / \mathrm{ml})$. (c right panel) MEFs CHOP ${ }^{-1-}$ and wild type were treated with oxLDLs $(200 \mu \mathrm{g} \mathrm{ApoB} / \mathrm{ml})$ and cell toxicity was analyzed as described. Results are expressed as percentage of untreated control and represent the mean \pm S.E.M. of three separate experiments ${ }^{* \star} P<0.01$ and ${ }^{\star} P<0.05$ indicate significance for the MTT test and apoptotic cells counting. For HMEC cells comparisons were made between OxLDL and OxLDL + HDL, OxLDL and OxLDL + JNK inhibitor or OxLDL and OxLDL + siCHOP groups), and for MEFs comparisons were made between wild-type and $\mathrm{CHOP}^{-1-}$ cells treated with oxLDL. (d) CHOP expression induced by oxLDLs is prevented by CHOP siRNA. Time course of CHOP expression in HMEC-1 cells treated with oxLDLs (200 $\mu \mathrm{g}$ ApoB/ml) following transfection with $100 \mathrm{nM}$ scramble (scr) siRNA or $100 \mathrm{nM} \mathrm{CHOP} \mathrm{siRNA.} \mathrm{Blots} \mathrm{are} \mathrm{representative} \mathrm{of} \mathrm{three} \mathrm{independent} \mathrm{experiments.} \mathrm{(e)} \mathrm{Morphological} \mathrm{characterization} \mathrm{of} \mathrm{cell} \mathrm{death} \mathrm{in} \mathrm{HMEC-1} \mathrm{cells}$ treated with oxLDLs $(200 \mu \mathrm{g} \mathrm{ApoB} / \mathrm{ml})$ or pre-incubated with HDLs $(200 \mu \mathrm{g} \mathrm{ApoA} / \mathrm{ml})$ for $1 \mathrm{~h}$. Upper panel, cells were stained with SYTO13/PI as described in the Materials and methods section and observed under inverted fluorescence microscope. Lower panel, cells were stained with May-Grunwald-Giemsa as described in the Materials and methods section. The results are representative of three separate experiments 
minor role on the whole apoptotic program (metabolic status and morphological characteristics of apoptosis explored by the MTT assay and SYTO13/PI labeling, respectively). Beclin-1 is involved in the phagocytic removal of dying cells during embryonic development through a mechanism that required PS exposure. ${ }^{30}$ Thus, we hypothesized that in our cellular model, Beclin-1 could contribute to PS exposure and phagocytosis of oxLDLs exposed cells. We checked whether Beclin-1 deficiency could modify the clearance of oxLDLs exposed HMEC-1 cells by macrophages. To analyze engulfment by macrophages, we used a well-characterized assay for phagocytosis. ${ }^{31}$ PKH26 (red dye)-labelled HMEC-1 transfected with Beclin-1 or scramble siRNA and treated with oxLDLs, were cocultured with PKH67 (green dye)-labelled $\mathrm{U}-937$ macrophages and the uptake of red-labelled HMEC-1

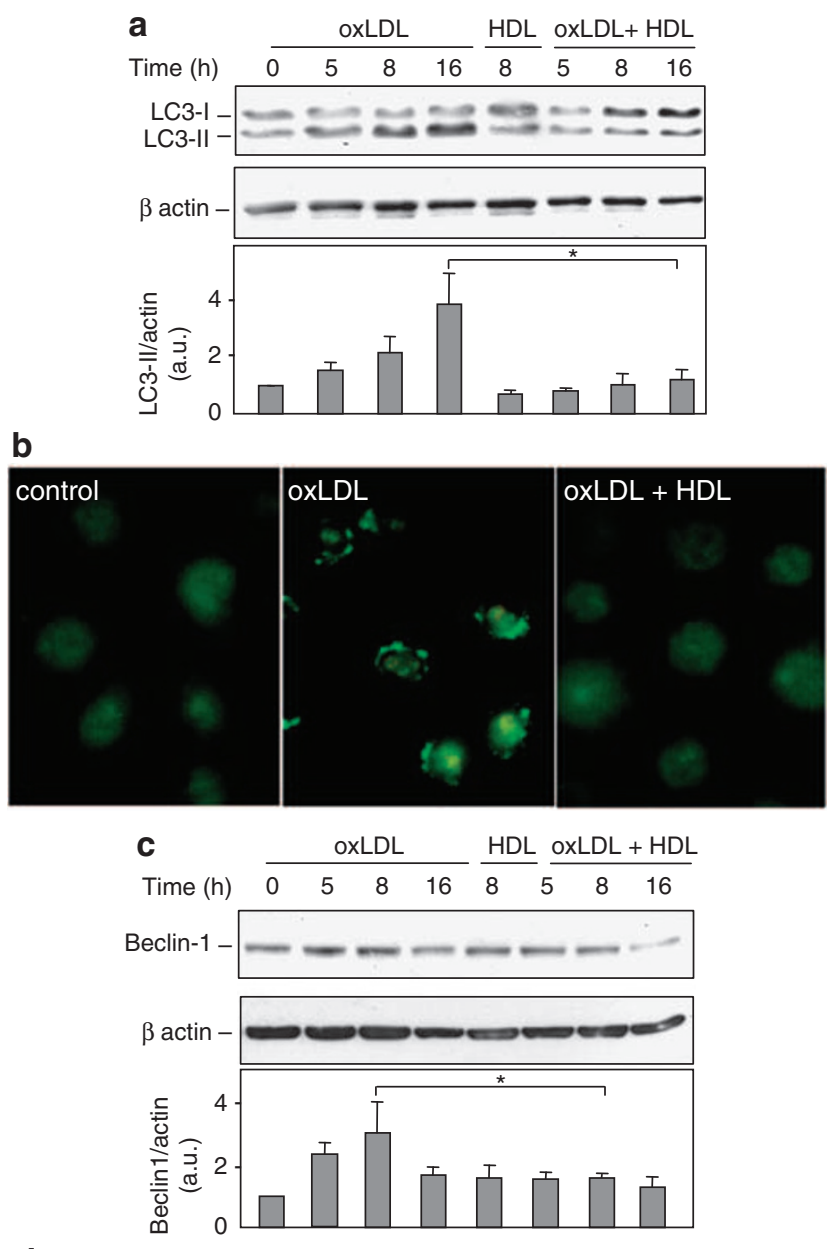

d

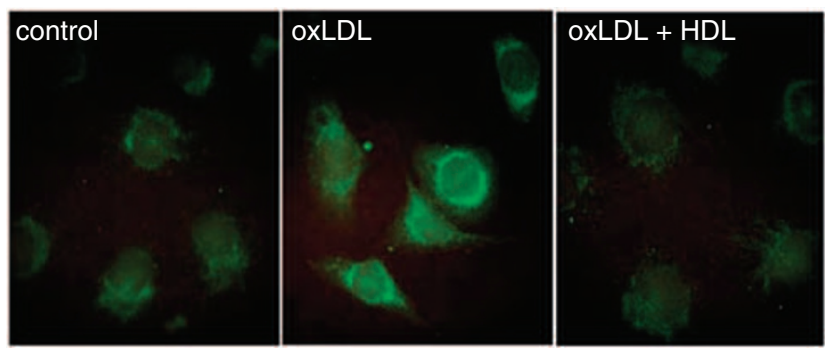

by green-labelled U-937 was measured by FACS analysis. The presence of double-positive cells (green and red cells, quadrant 2) indicated that the uptake of oxLDLs exposed HMEC-1 cells by macrophages is significantly reduced when HMEC-1 cells were silenced for Beclin-1 (Figure 6a and b). The data reported in Figure $5 c$ and Figure 6 are consistent, and suggest that Beclin-1 silencing reduced both $P S$ exposure in oxLDLs-treated HMEC-1 cells and the subsequent phagocytosis by macrophages.

Altogether, these results indicate that Beclin-1 may be involved in the generation of PS exposure and may be implicated in the phagocytic removal of PS-exposing cells. Thus, autophagy induction by oxLDLs could facilitate phagocytosis of oxLDLs exposed cells.

To investigate whether the ER stress-dependent (i.e., JNKand CHOP-mediated) proapoptotic pathways were implicated in the trigger of autophagic response, we analyzed LC3 processing after oxLDLs treatment in MEFs $\mathrm{CHOP}^{-1-}$ or wild type. The processing of LC3-I to LC3-II was not inhibited in MEFs $\mathrm{CHOP}^{-1-}$ compared with wild type (Figure 7a) and by the JNK inhibitor SP600125 (Figure 7b), thus, suggesting that this step of autophagy triggered by oxLDLs does not require the ER stress-dependent apoptotic pathway.

Taken together, these results suggest that ER stress is involved in oxLDLs-induced apoptosis and is blocked by HDLs. Like ER stress, autophagy is activated by oxLDLs, and is inhibited by HDLs. This led us to investigate whether both ER stress and autophagy are activated by a common signaling pathway evoked by oxLDLs, and possibly inhibited by HDLs.

Calcium mediates oxLDLs-induced ER stress and autophagy: inhibition by HDLs. We previously reported that oxLDLs-induced apoptosis results from a deregulation of the cytosolic $\mathrm{Ca}^{2+}$ homeostasis, characterized by a delayed and intense $\mathrm{Ca}^{2+}$ rise occurring several hours after the

Figure 3 HDLs inhibit oxLDLs-triggered LC3 processing and Beclin-1 expression in HMEC-1 cells. (a) Time course conversion of LC3-I to the phosphatidylethanolamine (PE)-conjugated form LC3-II in HMEC-1 cells treated by oxLDLs $(200 \mu \mathrm{g} \mathrm{ApoB} / \mathrm{ml})$ or pre-incubated with HDLs $(200 \mu \mathrm{g} \mathrm{ApoA} / \mathrm{ml})$ for $1 \mathrm{~h}$. Western blot experiments were performed on total protein extracts using anti-LC3 antibody and $\beta$-actin expression was used as loading control. The graph represents values of LC3-II band intensity after normalization for $\beta$-actin by densitometry, ${ }^{*} P<0.05$ indicates significance, comparison between OxLDL $14 \mathrm{~h}$ and OxLDL $14 \mathrm{~h}+\mathrm{HDL}$. Blots are representative of three independent experiments (b) Fixed cells were immunostained for LC3 and revealed LC3-positive signals with appearance of punctate structures under oxLDLs treatment $(200 \mu \mathrm{g} \mathrm{ApoB} / \mathrm{ml})$ and no LC3-positive signals when cells were pre-incubated with HDLs (200 $\mu \mathrm{g}$ ApoA/ml). The results are representative of three separate experiments. (c) Time course induction of Beclin-1 expression in HMEC-1 cells treated by oxLDLs (200 $\mu \mathrm{g}$ $\mathrm{ApoB} / \mathrm{ml})$ or pre-incubated with $\mathrm{HDLS}(200 \mu \mathrm{g} \mathrm{ApoA} / \mathrm{ml})$ for $1 \mathrm{~h}$. Western blot experiments were performed on total protein extracts using anti-Beclin-1 antibody and $\beta$-actin expression was used as loading control. The graph represents values of Beclin-1 band intensity after normalization for $\beta$-actin by densitometry, ${ }^{*} P<0.05$ indicates significance, comparison between OxLDL $8 \mathrm{~h}$ and OxLDL $8 \mathrm{~h}+\mathrm{HDL}$. Blots are representative of three independent experiments. (d) Fixed cells were immunostained for Beclin-1 and revealed some nuclear and perinuclear staining under oxLDLs treatment $(200 \mu \mathrm{g} \mathrm{ApoB} / \mathrm{ml})$ but inhibited by pre-incubation with HDLs $(200 \mu \mathrm{g} \mathrm{ApoA} / \mathrm{ml})$. The results are representative of three separate experiments 


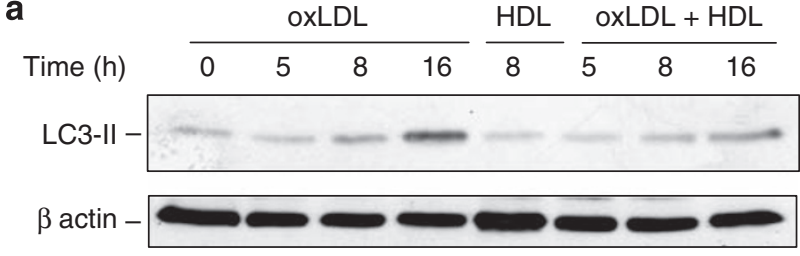

b

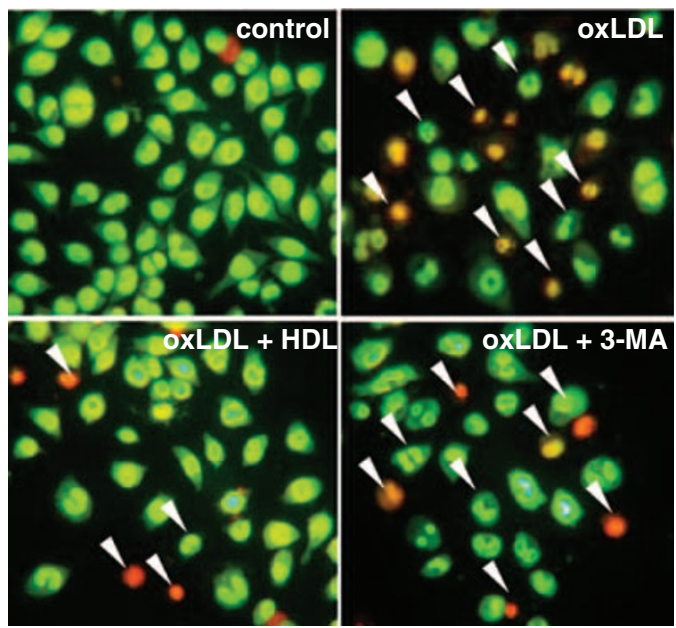

C

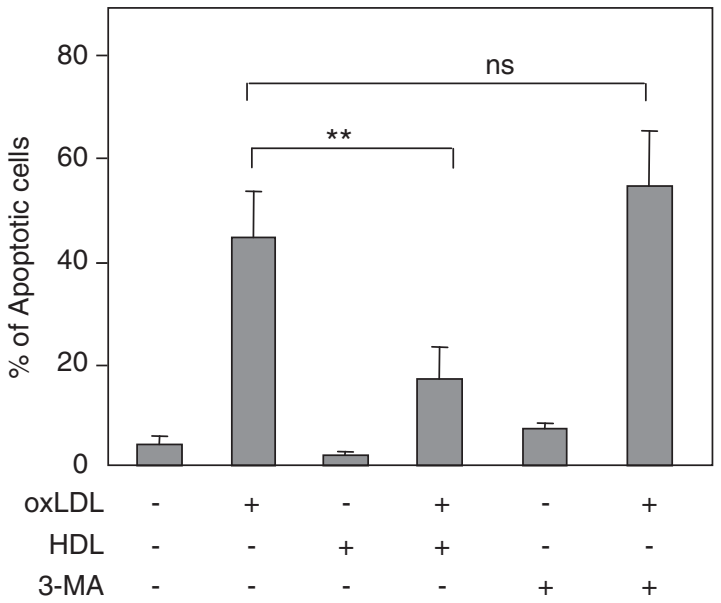

Figure 4 HDLs inhibit LC3 processing and cell death induced by oxLDLs in human macrophages. (a) Time course conversion of LC3-I to the phosphatidylethanolamine (PE)-conjugated form LC3-II in U937 cells treated by oxLDLs $(200 \mu \mathrm{g}$ $\mathrm{ApoB} / \mathrm{ml})$ or pre-incubated with $\mathrm{HDLs}(200 \mu \mathrm{g} \mathrm{ApoA} / \mathrm{ml})$ for $1 \mathrm{~h}$. Western blot experiments were performed on total protein extracts using anti-LC3 antibody and $\beta$-actin expression was used as loading control. (b) Morphological characterization of cell death in U937 cells treated with oxLDLs $(200 \mu \mathrm{g} \mathrm{ApoB} / \mathrm{ml})$ or pre-incubated with HDLs $(200 \mu \mathrm{g} \mathrm{ApoA} / \mathrm{ml})$ or 3-MA $(5 \mathrm{mM})$ for $1 \mathrm{~h}$. Cells were stained with SYTO13/PI as described in the Materials and methods section and observed under inverted fluorescence microscope. The results are representative of three separate experiments. (c) Apoptotic cells were counted after staining with SYTO13/PI. U937 cells were pre-treated with HDLs $(200 \mu \mathrm{g} \mathrm{ApoA} / \mathrm{ml})$ or 3-MA $(5 \mathrm{mM})$ then treated with oxLDLs $(200 \mu \mathrm{g} \mathrm{ApoB} / \mathrm{ml})$. Results are expressed as percentage of untreated control and represent the mean \pm S.E.M. of three separate experiments. ${ }^{*} P<0.01$ indicates significance, comparison between OxLDL and OxLDL $+\mathrm{HDL}$, ns means not significant for the comparison between OxLDL and OxLDL + 3-MA

beginning of the pulse with oxLDLs. ${ }^{5,8}$ Interestingly, HoyerHansen et al. ${ }^{14}$ demonstrate that a rise in free cytosolic $\mathrm{Ca}^{2+}$ is a potent inducer of autophagy which suggests that apoptosis and autophagy share many of the same regulators. The rise in cytosolic $\mathrm{Ca}^{2+}$ triggered by oxLDLs was completely blocked in cells pre-treated by HDLs (Figure 8a). To investigate whether the increase in cytosolic $\mathrm{Ca}^{2+}$ induced by oxLDLs may participate in the induction of ER stress and autophagy, HMEC-1 cells were pre-incubated with the $\mathrm{Ca}^{2+}$ chelator EGTA (which inhibits both calcium deregulation and apoptotic signaling induced by oxLDLs ${ }^{6,7}$ ). HMEC-1 cells pre-treatment with EGTA inhibited the overexpression of $\mathrm{CHOP}$, the nuclear translocation of ATF6 and the phosphorylation of elF2 $\alpha$ and JNK, all events triggered by oxLDLs (Figure $8 \mathrm{~b}-\mathrm{d}$ ). Likewise, the chelation of $\mathrm{Ca}^{2+}$ completely abolished the processing of LC3-I to LC3-II and the increase in Beclin-1 expression observed with oxLDLs treatment (Figure 8d).

Altogether, these results indicate that the cytosolic $\mathrm{Ca}^{2+}$ deregulation mediated by oxLDLs participates in the induction of ER-stress and autophagic responses. In addition, our data strongly suggest that HDLs, by inhibiting the $\mathrm{Ca}^{2+}$ rise induced by oxLDLs, prevent the activation of ER stress and autophagy.

\section{Discussion}

In this study, we report that ER stress induced by oxLDLs in human vascular cells, and involved in apoptosis, is inhibited by HDLs. We provide evidence that oxLDLs-induced autophagy is involved in PS exposure and contributes to the phagocytosis of oxLDL exposed cells. This autophagic response is inhibited by HDLs pre-treatment. Both ER stress and autophagy activation by oxLDLs depend on the deregulation of cytosolic $\mathrm{Ca}^{2+}$ homeostasis, also involved in apoptosis.

The first important result of this study is that ER stress induction by oxLDLs, and its subsequent ER stress-dependent apoptosis is inhibited by HDLs. We report that HDLs inhibit the phosphorylation of the proximal sensor of ER stress, IRE $1 \alpha$ and of the PERK substrate elF2 $\alpha$, as well as the activation of ATF6 triggered by oxLDLs. Moreover, and in agreement with the results of Gharavi et al., ${ }^{21}$ we found that HDLs prevent the induction of spliced XBP1 mRNA. As previously reported, oxLDLs triggered a long-lasting ER stress, that switched toward apoptosis, as supported by the increased expression of the proapoptotic transcription factor CHOP, which is induced through the three sensors ATF6, PERK and IRE $1 \alpha$ pathways. As expected from their inhibitory effect on the sensors, HDLs inhibit the induction of CHOP by oxLDLs. CHOP triggers the transcription of proapoptotic genes $^{32}$ and inhibits the antiapoptotic effect of Bcl-2. ${ }^{33}$ It's implication in atherosclerosis has been recently reported in mice double knock down for $\mathrm{CHOP}$ and ApoE, which exhibit a lower extent of atherosclerotic lesions, and less necrotic regions within the plaque. ${ }^{34}$ These data suggest that ER stress and particularly CHOP, may promote cell death within the vascular wall and atherosclerosis. Interestingly, HMEC-1 cells silenced for CHOP by siRNA, or fibroblasts issued from CHOP-/- mice, ${ }^{32}$ were partly resistant to the cytotoxic effect of oxLDLs, which supports a role for ER stress and $\mathrm{CHOP}$ in oxLDLs-mediated apoptosis, in agreement with Tabas et al. ${ }^{34}$ Moreover, we show that HDLs inhibit the phosphorylation of 
a
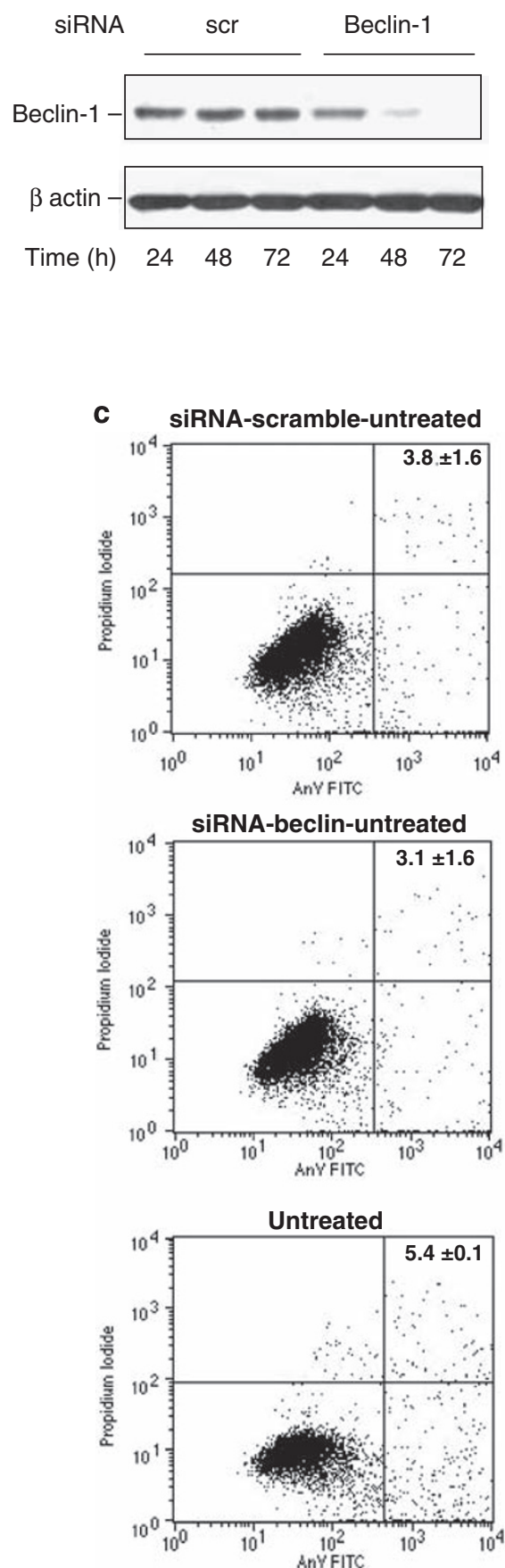
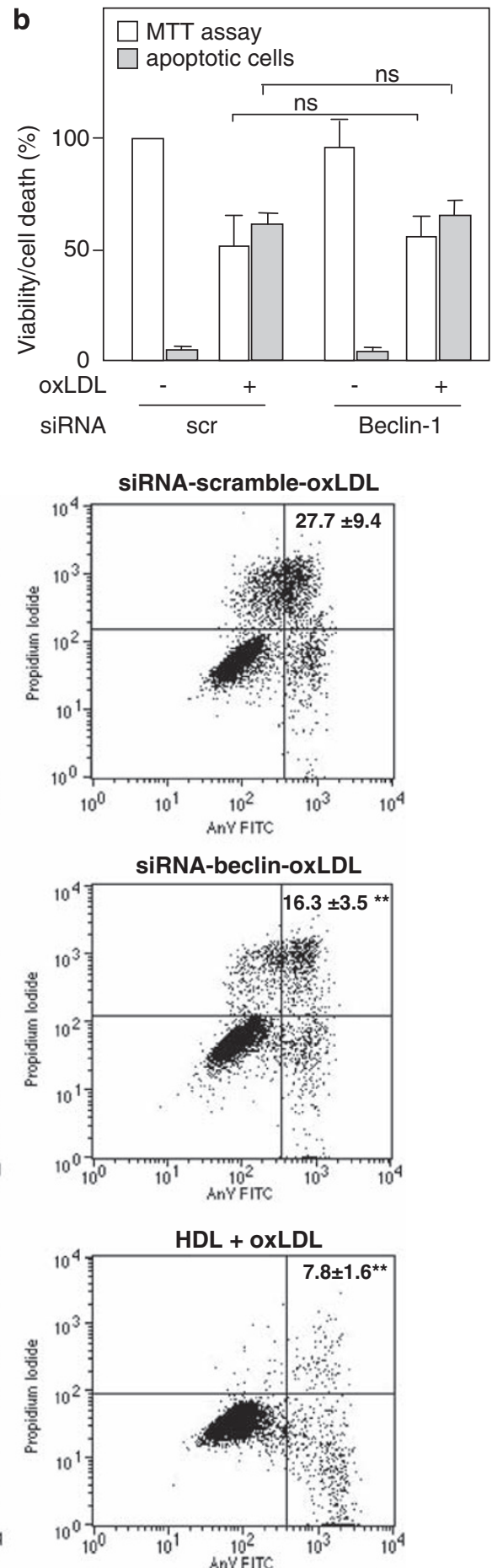

Figure 5 Beclin-1 is not involved in oxLDLs-induced cell death. (a) Time course of Beclin-1 expression in HMEC-1 cells transfected with $100 \mathrm{nM}$ scramble (scr) siRNA or $100 \mathrm{nM}$ beclin-1 siRNA. Western blot experiments were performed on total protein extracts using anti-beclin-1 antibody and $\beta$-actin expression was used as loading control. (b) OxLDLs-induced cell toxicity was evaluated by the MTT assay and apoptotic cells were counted after staining with SYTO13/PI. HMEC-1 cells were transfected with $100 \mathrm{nM}$ scramble siRNA or $100 \mathrm{nM}$ beclin-1 siRNA for $48 \mathrm{~h}$ then incubated with oxLDLs (200 $\mu \mathrm{g} \mathrm{ApoB} / \mathrm{ml})$. Results are expressed as percentage of untreated control and represent the mean \pm S.E.M. of three separate experiments, ns means not significant for the comparison between siRNA-scramble + OxLDL and siRNA-beclin + OxLDL. (c) Determination of cell death by flow cytometry of annexin V-FITC/PI staining in HMEC-1 cells transfected with $100 \mathrm{nM}$ siRNA scramble (scr) or $100 \mathrm{nM}$ siRNA beclin-1 for $48 \mathrm{~h}$ and then incubated with oxLDLs $(200 \mu \mathrm{g} \mathrm{ApoB} / \mathrm{ml})$. Antiapoptotic effect of HDLs were also assessed, HMEC-1 cells were pre-incubated with HDLs $(200 \mu \mathrm{g} \mathrm{ApoA} / \mathrm{ml})$ for $1 \mathrm{~h}$ then treated with oxLDLs $(200 \mu \mathrm{g} \mathrm{ApoB} / \mathrm{ml})$. Cells were labeled with annexin V-FITC and PI and analyzed by flow cytometry. Percentages (mean \pm S.E.M. of five independent experiments) of annexin $\mathrm{V}$-positive cells (annexin $\mathrm{V}^{+} / \mathrm{PI}^{-}$or annexin $\mathrm{V}^{+} / \mathrm{PI}^{+}$) cells are indicated. ${ }^{* \star} P<0.01$ indicates significance, comparisons were between siRNAscramble + OxLDL and siRNA-beclin1 + OxLDL or between siRNA-scramble + OxLDL and HDL + OxLDL 
a

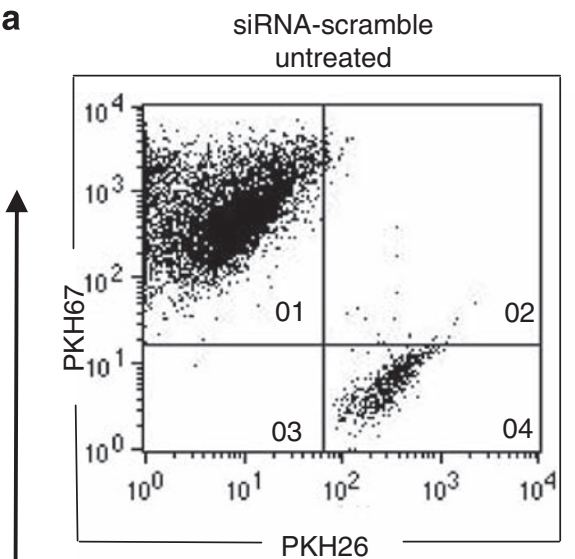

PKH26

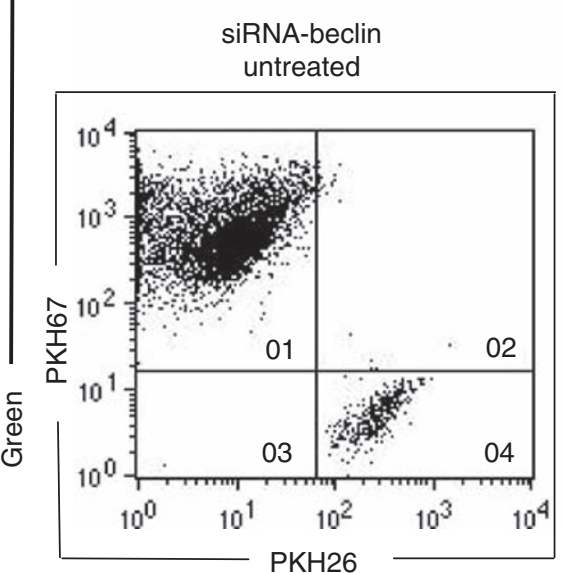

siRNA-scramble + oxLDL

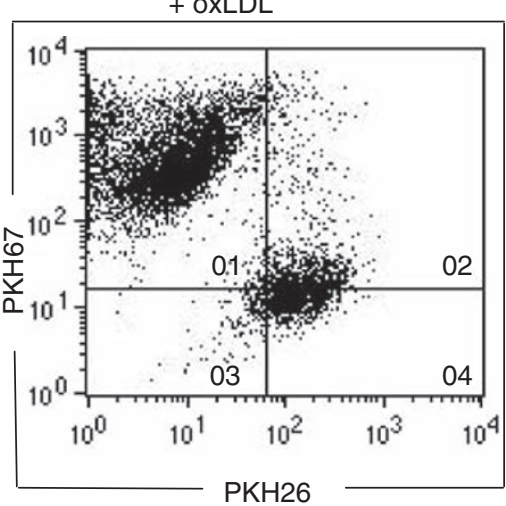

siRNA-beclin

+ oxLDL

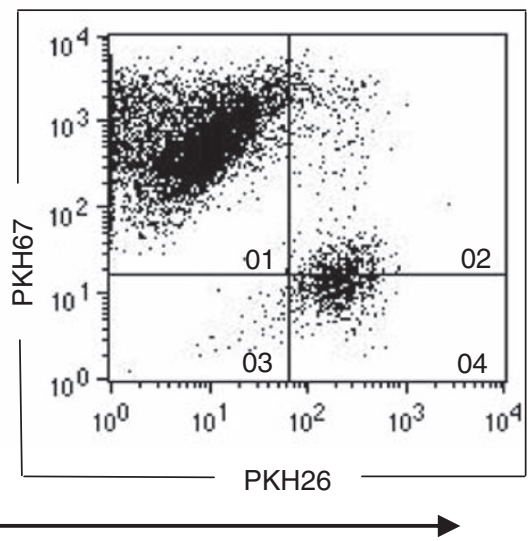

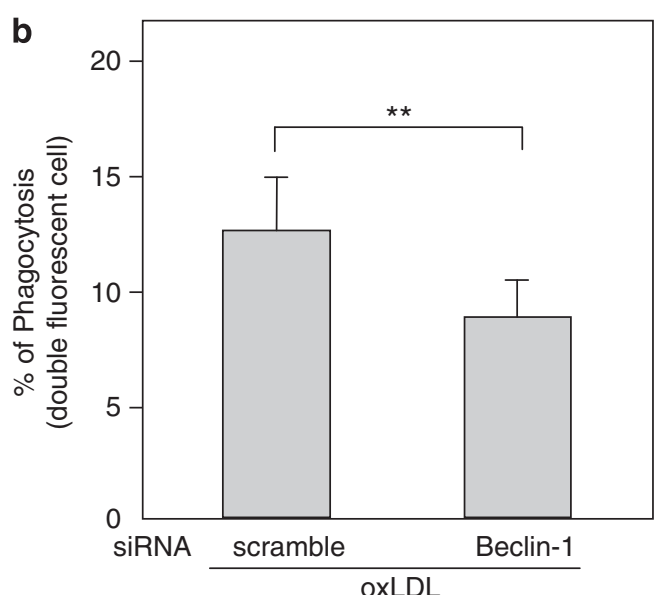

Figure 6 Beclin-1 is involved in phagocytosis of HMEC-1 cells exposed to oxLDLs. (a) Representative flow cytometry analysis of phagocytosis of apoptotic HMEC-1 cells by U-937 cells. PKH26-labelled HMEC-1 cells (red) transfected with $100 \mathrm{nM}$ siRNA scramble (scr) or $100 \mathrm{nM}$ siRNA beclin-1 and treated with oxLDLs (200 $\mu \mathrm{g} \mathrm{ApoB/ml)} \mathrm{or}$ untreated, were overlaid on PKH67-labelled U-937 cells (green). After $8 \mathrm{~h}$ of coculture, cells were harvested and analyzed using flow cytometry, quadrant 1 (upper left): green fluorescent macrophages only; quadrant 2 (upper right): double fluorescent macrophages phagocytosed apoptotic HMEC-1 cells, quadrant 4 (lower left): red fluorescent HMEC-1 cells only. (b) Bart chart shows the average of double fluorescent human macrophages that phagocytosed apoptotic HMEC-1 cells transfected with $100 \mathrm{nM}$ siRNA scramble (scr) or $100 \mathrm{nM}$ siRNA beclin-1 and treated with oxLDLs. Data are presented as mean \pm S.E.M. of four independent experiments. ${ }^{* *} P<0.01$ indicates significance, comparison was between siRNA-scramble + OxLDL and siRNA-beclin1 + OxLDL

JNK induced by oxLDLs, which in our system is activated by IRE $1 \alpha$, and is involved in ER stress-dependent apoptosis 9, via the JNK proapoptotic pathway, as reported. ${ }^{40}$ The effect of
oxLDLs and HDLs on ER stress-induced apoptosis is also favoured by caspase-12 processing that occurs upon oxLDLs stimulation and which is inhibited by HDLs in murine 

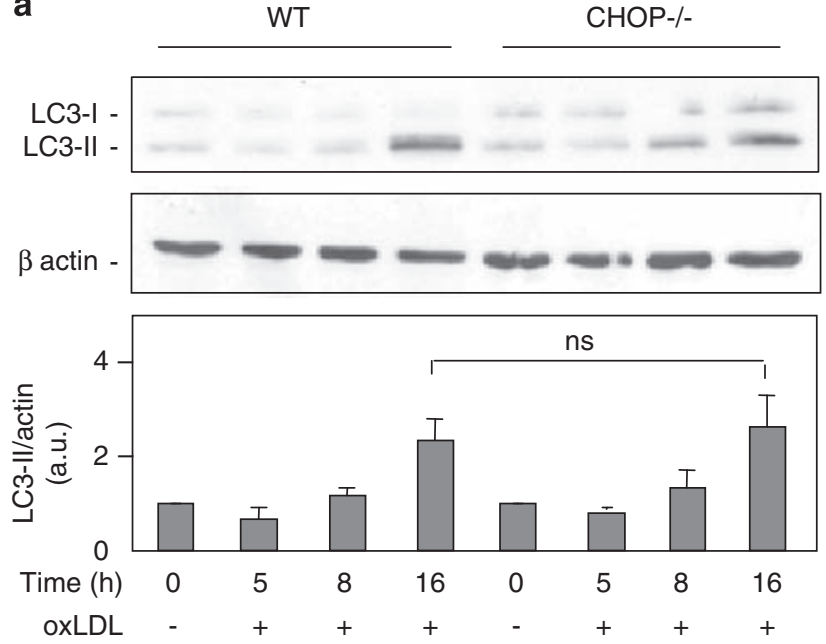

b Inhibitor
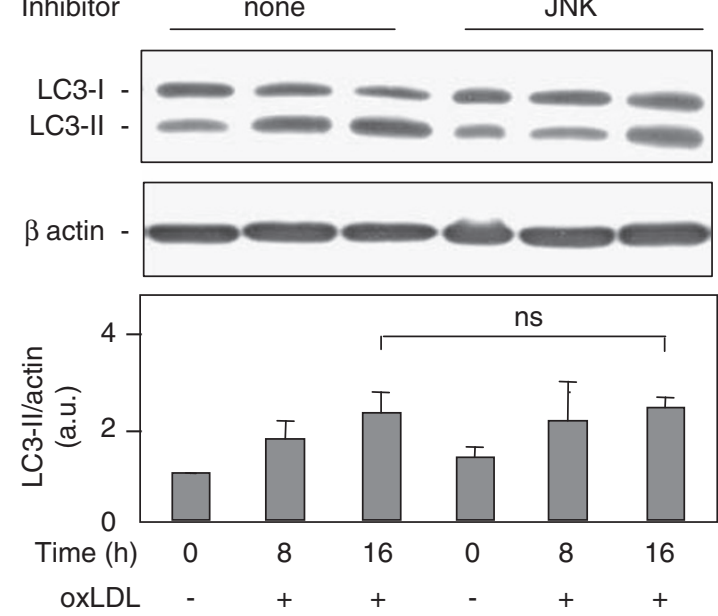

Figure 7 OxLDLs-induced autophagic response is independent of the ER stress-mediated apoptosis pathway. (a) Time course conversion of LC3-I to the phosphatidylethanolamine (PE)-conjugated form LC3-II in MEFs $\mathrm{CHOP}^{-1-}$ and wild-type cells treated with oxLDLs $(200 \mu \mathrm{g} \mathrm{ApoB} / \mathrm{ml})$. The graph represents values of LC3-II band intensity after normalization for $\beta$-actin by densitometry, ns means not significant for the comparison between OxLDL and OxLDL + HDL at the indicated times. (b) Time course conversion of LC3-I to the phosphatidylethanolamine (PE)-conjugated form LC3-II in HMEC-1 pre-incubated without (none) or with the JNK inhibitor SP600125 $(10 \mu \mathrm{mol} / \mathrm{l})$, then treated with oxLDLs $(200 \mu \mathrm{g} \mathrm{ApoB} /$ $\mathrm{ml}$ ). The graph represents values of LC3-II band intensity after normalization for $\beta$-actin by densitometry, ns means not significant for the comparison between OxLDL and OxLDL $+\mathrm{HDL}$ at the indicated times. Western blot experiments were performed on total protein extracts using anti-LC3 antibody and $\beta$-actin expression was used as loading control. Blots are representative of three separate experiments

endothelial cells. Our results are consistent with previous studies showing that caspase-12 could be the initiator caspase in ER-stress mediated apoptosis. ${ }^{25}$ However, the precise role of caspase-12 in human is still undefined and need further investigation as human caspase-12 gene encodes an aberrant caspase. Altogether, these data emphasize the inhibitory effect of HDLs on ER stress as a major feature in HDLs antiapoptotic mechanism.

To precise the mechanisms mediating the protective effects of HDLs, we examined the potential relationship of oxLDLs- induced ER stress with autophagy. Indeed, autophagy is thought to be a part of the ER stress response probably as an alternate to ER-associated protein degradation (ERAD) if the latter is overloaded. ${ }^{35}$ Autophagy is thought to alleviate ER stress and inhibit apoptosis, by mediating, in part, the removal of ER-accumulated protein, via the ER-associated chaperone $\mathrm{GRP} 78 / \mathrm{BiP}$, and the release of $\mathrm{Ca}^{2+}$ from the ER into the cytosol. However, in case of prolonged ER stress, the protective effect of autophagy may switch to cell death. ${ }^{15}$ The formation of LC3-II, as an essential step in the formation of the pre-autophagosome, and the increase in Beclin-1 expression are classical index of autophagy induction. ${ }^{12}$ In our experimental conditions, we observed a processing of LC3 and an increased expression in Beclin-1, concomitant with the activation of ER sensors by oxLDLs, indicating that autophagy is activated in HMEC-1 cells stimulated by oxLDLs. These data are consistent with recent reports showing that 7-ketocholesterol, a major oxysterol present in oxLDLs ${ }^{26}$ and lipid peroxidation-derived aldehyde (4-hydroxynonenal, 4-HNE) are potent autophagy and ER stress inducers. ${ }^{15}$ Indeed, increasing reports indicate that ER stress inducers (i.e., thapsigargin, tunicamycin) upregulate autophagyrelated genes, ${ }^{36}$ thus, connecting ER stress to autophagy by UPR activation. It may be noted that the use of SP600125 JNK inhibitor or MEFs $\mathrm{CHOP}^{-1-}$ (which protects, in part, against oxLDLs apoptosis), did not suppress LC3 processing, indicating that oxLDLs-induced autophagy is independent of the ER stress apoptotic pathway. Although autophagy could also represent a protective and survival mechanism, ${ }^{12}$ we showed that Beclin-1 silencing by siRNA and 3-MA did not alter the whole apoptotic program (metabolic status and morphological characteristics of apoptosis) induced by oxLDLs. Nevertheless, we observed that Beclin-1 silencing led to a decreased proportion of annexin V-positive cells, thus, suggesting that oxLDLs-triggered autophagy may be implicated in morphological changes such as PS exposure. Indeed, Qu et al. ${ }^{30}$ showed that Beclin-1 is dispensable for programmed cell death, but is essential for the generation of engulfment signals such as PS exposure which are required for dead-cell clearance during development. Using a phagocytosis assay, we found that HMEC-1 cells silenced for Beclin-1 and exposed to oxLDLs displayed less recognition and uptake by macrophages. These results suggest that oxLDLs exposed cells undergo autophagy activation and PS exposure (a 'eat-me' signal ${ }^{30}$ ) through a common mechanism involving Beclin-1. It is tempting to speculate that this process might be rather antiatherogenic by favouring the degradation of cellular components modified by oxidized lipids which are known to alter cell functions and to induce inflammatory and thrombotic events. ${ }^{37}$ In contrast to this protective role, the loss of endothelial cells (subsequent to PS exposure-induced phagocytosis) may lead to increased vascular permeability and platelet aggregation which may enhance the atherogenic process and the risk of thrombosis, respectively.

HDLs, used under antiapoptotic conditions, prevent also ER stress and autophagic response triggered by oxLDLs. To our knowledge, this is the first report showing that HDLs are able to prevent autophagy, but this result was unexpected, because HDLs are antiapoptotic, and because autophagy is generally considered as a protective mechanism. This 
a
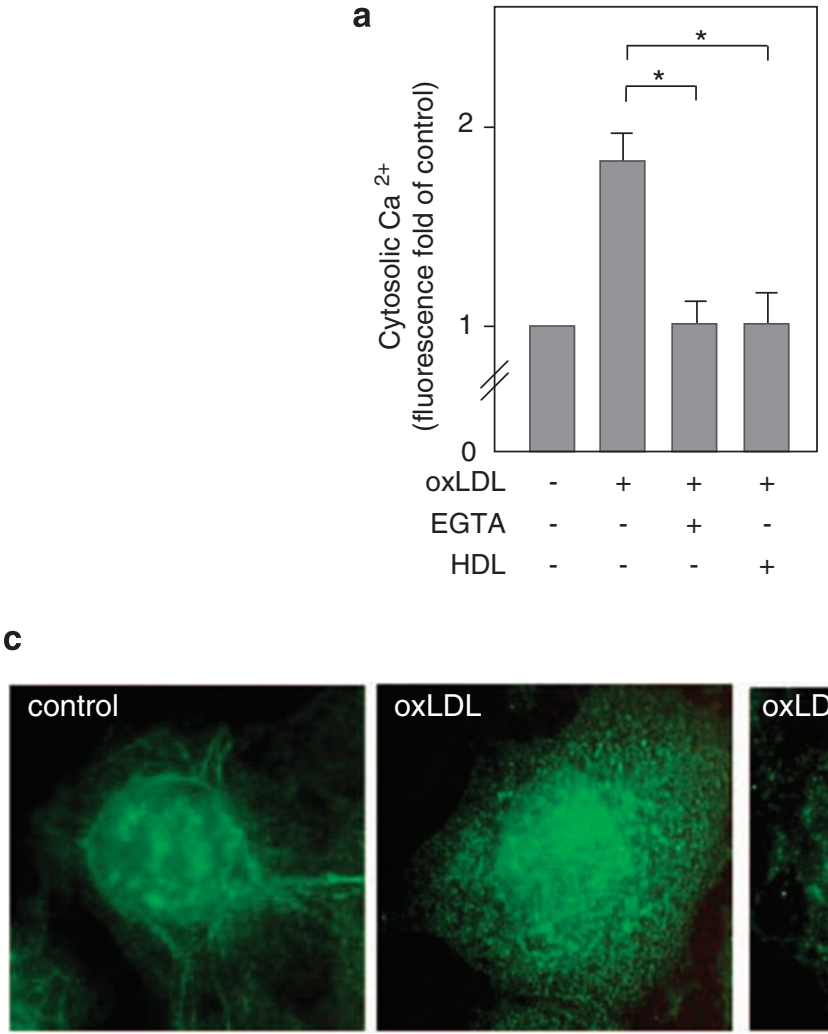

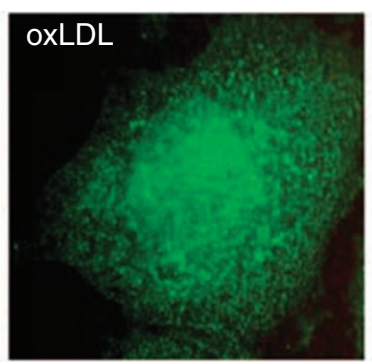

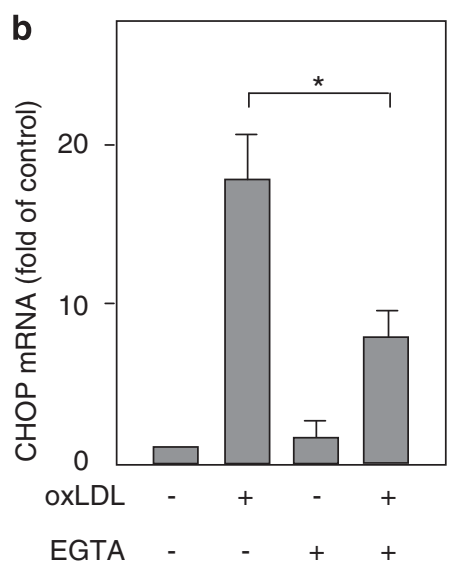

d p.elF2 $\alpha-$

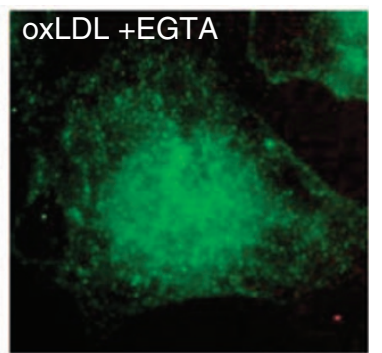

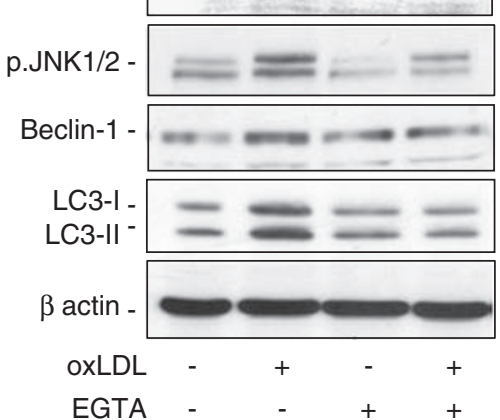

Figure 8 OxLDLs-induced cytosolic $\mathrm{Ca}^{2+}$ deregulation is inhibited by HDLs. ER stress and autophagy response triggered by oxLDLs are prevented by the $\mathrm{Ca}^{2+}$ chelator EGTA. (a) HMEC-1 cells were pre-incubated with EGTA $(0.4 \mathrm{mmol} / \mathrm{l})$ or HDLs ( $200 \mu \mathrm{g} \mathrm{ApoA} / \mathrm{ml})$ for $1 \mathrm{~h}$, then treated with oxLDLs $(200 \mu \mathrm{g} \mathrm{ApoB} / \mathrm{ml})$ for $12 \mathrm{~h}$. The variation of intracellular $\left(\mathrm{Ca}^{2+}\right)$ was detected by fluorescence intensity using Fluo3/AM (495 and $525 \mathrm{~nm}$ excitation and emission wavelength, respectively) as described under Materials and methods section. Results were normalized on protein levels and expressed in ratio to untreated control. The data are expressed as mean \pm S.E.M. of three separate experiments $\left({ }^{*} P<0.05\right.$ indicates significance, comparisons were made between $0 x L D L$ and OxLDL + EGTA or OxLDL and OxLDL + HDL). (b) Real-time PCR was performed to analyze CHOP mRNA expression levels. HMEC-1 cells were pre-incubated with or without EGTA $(0.4 \mathrm{mmol} / \mathrm{l})$ then treated with oxLDLs (200 $\mu \mathrm{g}$ ApoB/ml) for $16 \mathrm{~h}$. Relative mRNA levels were normalized to GAPDH mRNA. The data are expressed as mean \pm S.E.M. of three separate experiments $\left({ }^{\star} P<0.05\right.$ indicates significance, comparison between OxLDL and OxLDL + EGTA). (c) Immunocytochemistry experiments show the cytoplasmic and nuclear translocation of ATF6 in HMEC-1 cells preincubated with or without EGTA $(0.4 \mathrm{mmol} / \mathrm{l})$ then treated with oxLDLs $(200 \mu \mathrm{g} \mathrm{ApoB} / \mathrm{ml})$ for $16 \mathrm{~h}$. These data are representative of three separate experiments. (d) The phosphorylation of elF2 $\alpha$, JNK, the processing of LC3 and Beclin-1 expression was analyzed in HMEC-1 cells pre-incubated with or without EGTA (0.4 mmol/l) then treated with oxLDLs $(200 \mu \mathrm{g} \mathrm{ApoB} / \mathrm{ml})$ for $16 \mathrm{~h}$. Western blot experiments were performed on total protein extracts using anti-LC3, anti-phospho-elF2 $\alpha$ or anti-phospho JNK antibodies and $\beta$-actin expression was used as loading control. Blots are representative of three separate experiments

suggests that HDLs may act upstream by inhibiting a signaling pathway common to apoptosis and autophagy. We, therefore, hypothesized that $\mathrm{Ca}^{2+}$ signaling may constitute this critical trigger, as $\mathrm{Ca}^{2+}$ deregulation is involved in apoptosis ${ }^{6}$ and ER stress ${ }^{9}$ induced by oxLDLs, and is also implicated in autophagy. ${ }^{14,38}$ The reported data show, for the first time, that HDLs completely blocked ER stress and autophagy induced by oxLDLs by preventing the cytosolic $\mathrm{Ca}^{2+}$ rise. The crucial role of this common $\mathrm{Ca}^{2+}$ signaling pathway is supported by the effect of $\mathrm{Ca}^{2+}$ chelator EGTA that also prevents the $\mathrm{Ca}^{2+}$ rise, ER stress and autophagy. Our results are in agreement with the role of $\mathrm{Ca}^{2+}$ deregulation as ER stress inducer, with consequences in apoptosis. ${ }^{39}$ Moreover, recent studies highlight the role of $\mathrm{Ca}^{2+}$ as a potent inducer of autophagy, which is triggered by $\mathrm{Ca}^{2+}$ mobilizing stimuli such as ATP, thapsigargin and ionomycin that activate the $\mathrm{Ca}^{2+}$ /calmodulin-dependent protein kinase-kinase and consequently inhibit mTOR. ${ }^{14,31}$
The upstream mechanisms and potential targets of HDLs involved in $\mathrm{Ca}^{2+}$ deregulation are still unknown. However, the antioxidant properties of HDLs that inhibit intracellular oxidative stress mediated by oxLDLs, ${ }^{20}$ could explain their protective effect, as oxidative stress is a well-known inducer of ER stress and calcium deregulation ${ }^{9,39}$

In conclusion, our data show a potent implication of ER stress and CHOP in apoptosis mediated by oxLDLs in vascular cells, resulting from the deregulation of cytosolic $\mathrm{Ca}^{2+}$. These results also point out that the oxLDLs-induced ER stress is associated to autophagy activation, which is not involved in oxLDLs-mediated cell death machinery, but may contribute to PS exposure and subsequent phagocytosis of oxLDLs exposed cells. Our in vitro data suggest that HDLs by blocking the $\mathrm{Ca}^{2+}$ deregulation, and consequently both ER stress and autophagy, may reduce the level of ER stress and autophagy markers that are detected in early and advanced atherosclerotic lesions. $9,15,34,40$ 


\section{Materials and Methods}

Reagents. Anti-phospho-elF2 $\alpha$, anti-LC3, anti-beclin 1 and phospho-JNK were from Cell Signaling Technology (Danvers, MA, USA), anti-phospho-IRE1 $\alpha$ from Affinity BioReagents (Golden, CO, USA), anti-caspase 12 is from Acris Antibodies Gmbh (Hiddenhausen, DE, USA) and anti- $\beta$-actin from Sigma-Aldrich (Lyon, France). Secondary antibodies were from Santa Cruz Biotechnology (Tebu-Bio, Le-Perray-enYvelines, France). 3-(4,5-dimethylthiazol-2-yl)-2,5-diphenyltetrazolium bromide (MTT) was from Euromedex (Souffelweyersheim, France). 3-methyladenine (3-MA) was from Sigma-Aldrich. SYTO-13, propidium iodide (PI) and fluo-3 AM were from Molecular Probes (Invitrogen, San Diego, CA, USA).

Cell culture. Human microvascular endothelial cells (HMECs-1), obtained from CDC (Atlanta, GA, USA), were grown in MCDB-131 culture medium supplemented with $10 \%$ fetal calf serum, $100 \mathrm{U} / \mathrm{ml}$ penicillin and $100 \mu \mathrm{g} / \mathrm{ml}$ streptomycin. The U-937 human macrophage cell line obtained from ATCC (LGC Standards S.a.r.I, Molsheim, France), was grown in RPMI-1640 culture medium supplemented with $10 \%$ fetal calf serum, $100 \mathrm{U} / \mathrm{ml}$ penicillin and $100 \mu \mathrm{g} / \mathrm{ml}$ streptomycin. CRL-2181 (mouse endothelial cell line), obtained from ATCC, was grown in DMEM culture medium supplemented with $10 \%$ fetal calf serum, $100 \mathrm{U} / \mathrm{ml}$ penicillin and $100 \mu \mathrm{g} / \mathrm{ml}$ streptomycin. Mouse embryonic fibroblasts (MEFs) from $\mathrm{CHOP}^{-l-}$ animals and wild-type MEFs were a generous gift from David Ron (New York University Medical Center, NY, USA). MEFS $\mathrm{CHOP}^{-1-}$ and wild type were grown in DMEM culture medium supplemented with $10 \%$ fetal calf serum, as described. ${ }^{22}$ Cells were starved in serum-free medium for $24 \mathrm{~h}$ before LDL treatment.

Lipoproteins (LDLs and HDLs) isolation and LDLs oxidation. LDLs and HDLs from human pooled sera were prepared by ultracentrifugation, dialyzed against PBS containing $100 \mu \mathrm{M}$ EDTA. LDLs were mildly oxidized by UV-C + copper/EDTA $(5 \mu \mathrm{M})$ (oxLDLs) as previously reported. ${ }^{23}$ OxLDLs contained $4.2-7.4$ nmoles of thiobarbituric acid-reactive substances (TBARS) $\mu \mathrm{g}$ ApoB. Relative electrophoretic mobility (REM) and 2,4,6trinitrobenzenesulfonic acid (TNBS) reactive amino groups were 1.2-1.3 times and $85-92 \%$ of native LDLs, respectively.

siRNA knockdown of CHOP. CHOP siRNA were from Dharmacon (Surrey, UK) (ON-TARGET plus SMART POOL L-004819-00) (Dharmacon). SiRNAs were transfected using the Hiperfect reagent (Quiagen, Courtaboeuf, France) according to the manufacturer's recommendations.

Evaluation of cytotoxicity, necrosis and apoptosis. For cytotoxicity experiments, cells were serum starved for $24 \mathrm{~h}$ and stimulated for the indicated times at $37^{\circ} \mathrm{C}$. Cytotoxicity was evaluated using the MTT test, as previously used. ${ }^{8}$ This method is based on MTT reduction by the respiratory chain and other electron transport systems leading to form non-water-soluble violet formazan crystals that can be determined spectrophotometrically (OD measured at $570 \mathrm{~nm}$ ) and serves as an estimate for the metabolic activity of living cells. Apoptotic and necrotic cells were counted after fluorescent staining by two fluorescent dyes, the permeant DNA intercalating green fluorescent probe SYTO-13 $(0.6 \mu \mathrm{M})$ and the non-permeant DNA intercalating red fluorescent probe $\mathrm{Pl}(15 \mu \mathrm{M})$ using an inverted fluorescence microscope (Fluovert FU, Leitz, Leica, Wetzlar, Germany). ${ }^{6}$ Normal nuclei exhibit a loose green-colored chromatin. Nuclei of primary necrotic cells exhibit loose redcolored chromatin. Apoptotic nuclei exhibited condensed yellow/green-colored chromatin associated with nucleus fragmentation, whereas post-apoptotic necrotic cells exhibited the same morphological features, but were red colored.

Annexin V/PI double staining and FACS analysis. Flow cytometry experiments after annexin V-FITC labeling were performed to evaluate PS externalization, an early event of apoptosis. After specific treatment, HMEC-1 was collected, re-suspended and stained with annexin V-FITC/PI (human annexin VFITC kit, AbCys SA, Paris, France) according to the manufacturer's instructions. Cells were analyzed on a FACScan (BD Biosciences, Le Pont de Claix, France) flowcytometer using 488-nm excitation and a 515-nm band-pass filter for fluorescein detection and a filter $>600 \mathrm{~nm}$ for PI detection. Data analysis was performed with Cell Quest software (Becton Dickinson Co., Mountain View, CA, USA). After appropriate markings for negative and positive populations, the percentage of annexin $\mathrm{V}^{+} / \mathrm{PI}^{-}$and annexin $\mathrm{V}^{+} / \mathrm{PI}^{+}$cells was determined and compared with untreated controls.

Phagocytosis analysis. HMEC-1 cells transfected with siRNA scramble or with siRNA beclin-1 were dyed red using PKH26, and U-937 cells were dyed green using PKH67, according to the manufacturer's instructions of the PKH26-GL/ PKH67-GL kit (Sigma-Aldrich). Labeled HMEC-1 cells were treated with oxidized LDL for $24 \mathrm{~h}$ to undergo apoptotic cell. PKH26-labelled HMEC-1 cells were carefully removed and washed with PBS, and overlaid on PKH67-labelled U-937 cells. Cocultured cells were harvested at $8 \mathrm{~h}$ by treatment with $0.02 \%$ trypsin EDTA. Detached cells were collected, washed with PBS and labeled cells were analyzed on a FACScan (BD Biosciences) flow cytometer using 488-nm blue laser for PKH67 and 532-nm green laser for PKH26. The negative control sample was prepared using red HMEC-1 and green U-937 cells that had been cultured separately and mixed before FACS analysis. The PKH67 and PKH26 double population was defined as U-937 cells containing phagocytosed HMEC-1 cells.

Western blot analysis. After stimulation of HMEC-1 under the conditions indicated in the text, cells were washed in phosphate-buffered saline (PBS) containing $1 \mathrm{mM}$ orthovanadate and $1 \mathrm{mM}$ phenylmethylsulfonyl fluoride. Cells were lysed in solubilizing buffer (10 mM Tris pH 7.4, $150 \mathrm{mM} \mathrm{NaCl}, 1 \%$ Triton X-100, $1 \%$ sodium deoxycholate, $0.1 \%$ SDS, $1 \mathrm{mM}$ sodium orthovanadate, $1 \mathrm{mM}$ sodium pyrophosphate, $5 \mathrm{mM}$ sodium fluoride, $1 \mathrm{mM}$ phenylmethylsulfonyl fluoride, $1 \mu \mathrm{g} / \mathrm{ml}$ leupeptin and $1 \mu \mathrm{g} / \mathrm{ml}$ aprotinin) for $30 \mathrm{~min}$ on ice. In total, $40 \mu \mathrm{g}$ of protein cell extracts was resolved by SDS-PAGE and transferred onto PVDF membranes (Millipore, Molsheim, France). Then membranes were probed with the indicated primary antibodies and revealed with the secondary antibodies coupled to horseradish peroxidase using the ECL chemoluminescence kit. Membranes were then stripped and re-probed with anti- $\beta$-actin antibody to control equal loading of proteins.

Real-time PCR. Cells were trypsinized and washed in PBS, then diluted in SV RNA lysis buffer (Promega, Charbonnières-les-Bains, France). Total extract was purified with SV Total isolation system (Promega) and $1 \mu \mathrm{g}$ of total RNA was used for reverse transcription (high capacity cDNA reverse transcription kit Applied Biosystems, Courtaboeuf, France).

Real-time quantitative PCR analysis, used to evaluate mRNA levels of CHOP, spliced XBP1 and GAPDH, utilized the above cited primers, CHOP forward $5^{\prime}$-CAGATGAAAATGGGGGTACCT-3' , reverse $5^{\prime}$-AGAAGCAGGGTCAAGAGTG GT-3', spliced XBP1 forward 5'-GCAGGTGCAGGCCCAGT-3', reverse 5'-GAATG CCCAACAGGATATCAGACT-3'), GAPDH forward $5^{\prime}$-CCTCCCGCTTCGCTCTC T-3', reverse $5^{\prime}$-GCTGGCGACGCAAAAGA-3'. The Fast SYBR Green MasterMix (Applied Biosystems) and the StepOne Plus Real-Time PCR System (Applied Biosytems) were used to detect the real-time quantitative PCR products of reversetranscribed cDNA samples according to the manufacturer's instructions. The following incubation conditions were followed: $95^{\circ} \mathrm{C}$ for $20 \mathrm{~s}$, followed by 40 cycles of $3 \mathrm{~s}$ at $95^{\circ} \mathrm{C}$, annealing/extension for $30 \mathrm{~s}$, at $60^{\circ} \mathrm{C}$. For each sample, PCR was done in duplicate for both the target genes and GAPDH control. The data were analyzed using StepOne Software v2.0.

Measurement of intracellular $\mathrm{Ca}^{2+}$. Cytosolic $\mathrm{Ca}^{2+}$ was determined using fluo3/AM according to Jagnadan et $\left.a\right|^{24}$. Briefly, cells were incubated with a loading solution consisting of HEPES-buffered saline (HBS; $135 \mathrm{mM} \mathrm{NaCl}, 5.9 \mathrm{mM}$ $\mathrm{KCl}, 1.2 \mathrm{mM} \mathrm{MgCl}_{2}, 1.5 \mathrm{mM} \mathrm{CaCl}_{2}, 11.6 \mathrm{mM}$ HEPES and $11.5 \mathrm{mM}$ glucose, $\mathrm{pH} 7.3$ ) supplemented with $5 \mu \mathrm{M}$ fluo-3/AM, $0.02 \%$ pluronic F-127 and $1 \mathrm{mg} / \mathrm{ml}$ bovine serum albumin for $30 \mathrm{~min}$ and then incubated in the loading solution without Fluo-3 for $30 \mathrm{~min}$ to allow de-esterification of the probe. Loading solution was then replaced with HBS, and cells were placed in a fluorometer and fluorescence was recorded ( 495 and $525 \mathrm{~nm}$ excitation and emission wavelengths respectively). Results were normalized on protein levels and expressed in ratio of control.

Immunofluorescence. Cells grown on cover glass slides were washed with PBS and fixed in PBS/4\% paraformaldehyde for $10 \mathrm{~min}$. After blocking with PBS containing $3 \% \mathrm{BSA}$ for $30 \mathrm{~min}$, cells were incubated with the indicated antibodies for $1 \mathrm{~h}$ and revealed with Alexa Fluor-conjugated secondary antibody for $1 \mathrm{~h}$. The slides were visualized using a Zeiss LSM 510 fluorescence confocal microscope (Zeiss, Le Pecq, France).

May-Grunwald-Giemsa staining. May-Grunwald-Giemsa staining (Merck, Fontenay Sous Bois, France) of methanol-fixed preparations was examined to identify the apoptotic cells on the basis of the following morphological criteria: nuclear shrinkage and chromatin condensation, cytoplasmic membrane blebbing, reduction of cell volume and formation of apoptotic bodies. 
Statistical analysis. Data are given as mean \pm S.E.M. Statistical comparison of the data was performed using the $t$-test for comparison between two groups and is explained in the figure legends (Sigma stat software). Values of $P<0.05$ were considered statistically significant.

\section{Conflict of interest}

The authors declare no conflict of interest.

Acknowledgements. This work was supported by Institut National de la Santé et de la Recherche Médicale, Université Toulouse-3, la 'Fondation Cœur et Artères' no FCA06T6, et la Fondation pour la Recherche Médicale, no DCV2007040927. CM is a recipient of a 'Fondation pour la Recherche Medicale' fellowship. We acknowledge JC Thiers and C Bernis for their excellent technical assistance. We are grateful to Prof. D Ron for providing MEFs CHOP-/- and wild-type cells and Dr. V Gallet (SNCF Laboratory, Toulouse) for providing human serum.

1. Lusis AJ. Atherosclerosis. Nature 2000; 407: 233-241.

2. Napoli C. Oxidation of LDL, atherogenesis, and apoptosis. Ann NY Acad Sci 2003; 1010 698-709.

3. Salvayre R, Auge N, Benoist $\mathrm{H}$, Negre-Salvayre A. Oxidized low-density lipoproteininduced apoptosis. Biochim Biophys Acta 2002; 1585: 213-221.

4. Steinberg D, Parthasarathy S, Carew TE, Khoo JC, Witztum JL. Beyond cholesterol. Modifications of low-density lipoprotein that increase its atherogenicity. N Engl J Med 1989; 320: $915-924$

5. Escargueil-Blanc I, Salvayre R, Negre-Salvayre A. Necrosis and apoptosis induced by oxidized low density lipoproteins occur through two calcium-dependent pathways in lymphoblastoid cells. Faseb J 1994; 8: 1075-1080.

6. Vindis C, Elbaz M, Escargueil-Blanc I, Auge N, Heniquez A, Thiers JC et al. Two distinct calcium-dependent mitochondrial pathways are involved in oxidized LDL-induced apoptosis. Arterioscler Thromb Vasc Biol 2005; 25: 639-645.

7. Ingueneau $C$, Huynh-Do U, Marcheix B, Athias A, Gambert $P$, Negre-Salvayre $A$ et al TRPC1 is regulated by caveolin-1 and is involved in oxidized LDL-induced apoptosis of vascular smooth muscle cells. J Cell Mol Med 2008; 14: 14

8. Robbesyn F, Auge N, Vindis C, Cantero AV, Barbaras R, Negre-Salvayre A et al. Highdensity lipoproteins prevent the oxidized low-density lipoprotein-induced epidermal [corrected] growth factor receptor activation and subsequent matrix metalloproteinase-2 upregulation. Arterioscler Thromb Vasc Biol 2005; 25: 1206-1212.

9. Sanson M, Auge N, Vindis C, Muller C, Bando Y, Thiers JC et al. Oxidized Low-Density Lipoproteins Trigger Endoplasmic Reticulum Stress in Vascular Cells Prevention by Oxygen-Regulated Protein 150 Expression. Circ Res 2009; 104: 328-336.

10. Oyadomari S, Mori M. Roles of CHOP/GADD153 in endoplasmic reticulum stress. Cell Death Differ 2004; 11: 381-389.

11. Boyce M, Yuan J. Cellular response to endoplasmic reticulum stress: a matter of life or death. Cell Death Differ 2006; 13: 363-373.

12. Yorimitsu T, Klionsky DJ. Autophagy: molecular machinery for self-eating. Cell Death Differ 2005; 12 (Suppl 2): 1542-1552.

13. Li J, Ni M, Lee B, Barron E, Hinton DR, Lee AS. The unfolded protein response regulator GRP78/BiP is required for endoplasmic reticulum integrity and stress-induced autophagy in mammalian cells. Cell Death Differ 2008; 15: 1460-1471.

14. Hoyer-Hansen M, Bastholm L, Szyniarowski P, Campanella M, Szabadkai G, Farkas T et al. Control of macroautophagy by calcium, calmodulin-dependent kinase kinase-beta, and Bcl-2. Mol Cell 2007; 25: 193-205.

15. Martinet W, De Meyer GR. Autophagy in atherosclerosis: a cell survival and death phenomenon with therapeutic potential. Circ Res 2009; 104: 304-317.

16. Maiuri MC, Zalckvar E, Kimchi A, Kroemer G. Self-eating and self-killing: crosstalk between autophagy and apoptosis. Nat Rev Mol Cell Biol 2007; 8: 741-752.

17. Assmann G, Nofer JR. Atheroprotective effects of high-density lipoproteins. Annu Rev Med 2003; 54: 321-341.
18. Negre-Salvayre A, Dousset N, Ferretti G, Bacchetti T, Curatola G, Salvayre R. Antioxidant and cytoprotective properties of high-density lipoproteins in vascular cells. Free Radic Biol Med 2006; 41: 1031-1040.

19. Mineo C, Deguchi H, Griffin JH, Shaul PW. Endothelial and antithrombotic actions of HDL. Circ Res 2006; 98: 1352-1364.

20. Robbesyn F, Garcia V, Auge N, Vieira O, Frisach MF, Salvayre R et al. HDL counterbalance the proinflammatory effect of oxidized LDL by inhibiting intracellular reactive oxygen species rise, proteasome activation, and subsequent NF-kappaB activation in smooth muscle cells. FASEB J 2003; 17: 743-745.

21. Gharavi NM, Gargalovic PS, Chang I, Araujo JA, Clark MJ, Szeto WL et al. High-density ipoprotein modulates oxidized phospholipid signaling in human endothelial cells from proinflammatory to anti-inflammatory. Arterioscler Thromb Vasc Biol 2007; 27: 1346-1353.

22. Zinszner H, Kuroda M, Wang X, Batchvarova N, Lightfoot RT, Remotti $\mathrm{H}$ et al. CHOP is implicated in programmed cell death in response to impaired function of the endoplasmic reticulum. Genes Dev 1998; 12: 982-995.

23. Vindis C, Escargueil-Blanc I, Elbaz M, Marcheix B, Grazide MH, Uchida K et al Desensitization of platelet-derived growth factor receptor-beta by oxidized lipids in vascula cells and atherosclerotic lesions: prevention by aldehyde scavengers. Circ Res 2006; 98 : 785-792.

24. Jagnandan D, Church JE, Banfi B, Stuehr DJ, Marrero MB, Fulton DJ. Novel mechanism of activation of NADPH oxidase 5. calcium sensitization via phosphorylation. $J$ Biol Chem 2007; 282: 6494-6507.

25. Oyadomari S, Araki E, Mori M. Endoplasmic reticulum stress-mediated apoptosis in pancreatic beta-cells. Apoptosis 2002; 7: 335-345.

26. Martinet W, De Bie M, Schrijvers DM, De Meyer GR, Herman AG, Kockx MM. 7-ketocholesterol induces protein ubiquitination, myelin figure formation, and light chain 3 processing in vascular smooth muscle cells. Arterioscler Thromb Vasc Biol 2004; 24: 2296-2301.

27. Nowicki M, Zabirnyk O, Duerrschmidt N, Borlak J, Spanel-Borowski K. No upregulation of lectin-like oxidized low-density lipoprotein receptor-1 in serum-deprived EA.hy926 endothelial cells under oxLDL exposure, but increase in autophagy. Eur $\mathrm{J}$ Cell Biol 2007; 86: 605-616.

28. Xie Z, Klionsky DJ. Autophagosome formation: core machinery and adaptations. Nat Cell Biol 2007: 9: 1102-1109.

29. Liang XH, Jackson S, Seaman M, Brown K, Kempkes B, Hibshoosh $\mathrm{H}$ et al. Induction of autophagy and inhibition of tumorigenesis by beclin 1. Nature 1999; 402: 672-676.

30. Qu X, Zou Z, Sun Q, Luby-Phelps K, Cheng P, Hogan RN et al. Autophagy gene-dependent clearance of apoptotic cells during embryonic development. Cell 2007 128: 931-946.

31. Uhl M, Kepp O, Jusforgues-Saklani H, Vicencio JM, Kroemer G, Albert ML. Autophagy within the antigen donor cell facilitates efficient antigen cross-priming of virus-specific CD8+ T cells. Cell Death Differ 2009; 16: 991-1005.

32. Marciniak SJ, Yun CY, Oyadomari S, Novoa I, Zhang Y, Jungreis R et al. CHOP induces death by promoting protein synthesis and oxidation in the stressed endoplasmic reticulum. Genes Dev 2004; 18: 3066-3077.

33. McCullough KD, Martindale JL, Klotz LO, Aw TY, Holbrook NJ. Gadd153 sensitizes cells to endoplasmic reticulum stress by down-regulating $\mathrm{Bcl} 2$ and perturbing the cellular redox state. Mol Cell Biol 2001; 21: 1249-1259.

34. Thorp E, Li G, Seimon TA, Kuriakose G, Ron D, Tabas I. Reduced apoptosis and plaque necrosis in advanced atherosclerotic lesions of Apoe-/- and Ldlr-/- mice lacking CHOP. Cell Metab 2009; 9: 474-481.

35. Kruse KB, Brodsky JL, McCracken AA. Autophagy: an ER protein quality control process. Autophagy 2006; 2: 135-137.

36. Yorimitsu T, Nair U, Yang Z, Klionsky DJ. Endoplasmic reticulum stress triggers autophagy Jiol Chem 2006; 281: 30299-30304.

37. Negre-Salvayre A, Auge N, Ayala V, Basaga H, Boada J, Brenke R et al. Pathological aspects of lipid peroxidation. Free Radic Res 2010; 44: 1125-1171.

38. Vicencio JM, Ortiz C, Criollo A, Jones AW, Kepp O, Galluzzi L et al. The inosito 1,4,5-trisphosphate receptor regulates autophagy through its interaction with Beclin 1. Cell Death Differ 2009; 16: 1006-1017.

39. Orrenius S, Zhivotovsky B, Nicotera P. Regulation of cell death: the calcium-apoptosis link Nat Rev Mol Cell Biol 2003; 4: 552-565.

40. Zhou J, Lhotak S, Hilditch BA, Austin RC. Activation of the unfolded protein response occurs at all stages of atherosclerotic lesion development in apolipoprotein E-deficient mice. Circulation 2005; 111: 1814-1821. 